\title{
Lithosphere tearing along STEP faults and synkinematic formation of lherzolite and wehrlite in the shallow subcontinental mantle
}

\author{
Károly Hidas $^{1,2}$, Carlos J. Garrido ${ }^{1}$, Guillermo Booth-Rea ${ }^{2}$, Claudio Marchesi ${ }^{1,3}$, Jean-Louis Bodinier ${ }^{4}$, \\ Jean-Marie Dautria ${ }^{4}$, Amina Louni-Hacini ${ }^{5}$, and Abla Azzouni-Sekkal ${ }^{5,6}$ \\ ${ }^{1}$ Instituto Andaluz de Ciencias de la Tierra, CSIC \& Universidad de Granada, Av. de las Palmeras 4, \\ 18100 Armilla, Granada, Spain \\ ${ }^{2}$ Departamento de Geodinámica, Facultad de Ciencias, Universidad de Granada, Campus de Fuentenueva s/n, \\ 18071 Granada, Spain \\ ${ }^{3}$ Departamento de Mineralogía y Petrología, Facultad de Ciencias, Universidad de Granada, Campus de Fuentenueva s/n, \\ 18071 Granada, Spain \\ ${ }^{4}$ Géosciences Montpellier, UMR 5243, CNRS \& Université de Montpellier, Place E. Bataillon, 34095 Montpellier, France \\ ${ }^{5}$ Faculté des Sciences de la Terre, de Géographie et de l'Aménagement du Territoire - Université des Sciences et de la \\ Technologie Houari Boumédiène - Laboratoire de Métallogénie et Magmatisme de l’Algérie, 32, El Alia, 16111, Bab \\ Ezzouar, Algiers, Algeria \\ ${ }^{6}$ Faculté des Sciences de la Nature et de la Vie et des Sciences de la Terre et de l'Univers, Université Abou Bekr Belkaïd, BP \\ 119, 13000, Tlemcen, Algeria
}

Correspondence: Károly Hidas (karoly.hidas@csic.es)

Received: 15 February 2019 - Discussion started: 27 February 2019

Revised: 31 May 2019 - Accepted: 12 June 2019 - Published: 10 July 2019

\begin{abstract}
Subduction-transform edge propagator (STEP) faults are the locus of continual lithospheric tearing at slab edges, resulting in sharp changes in the lithospheric and crustal thickness and triggering lateral and/or near-vertical mantle flow. However, the mechanisms at the lithospheric mantle scale are still poorly understood. Here, we present the microstructural study of olivine-rich lherzolite, harzburgite and wehrlite mantle xenoliths from the Oran volcanic field (Tell Atlas, northwest Algeria). This alkali volcanic field occurs along a major STEP fault responsible for the Miocene westward slab retreat in the westernmost Mediterranean. Mantle xenoliths provide a unique opportunity to investigate the microstructures in the mantle section of a STEP fault system.

The microstructures of mantle xenoliths show a variable grain size ranging from coarse granular to fine-grained equigranular textures uncorrelated with lithology. The major element composition of the mantle peridotites provides temperature estimates in a wide range $\left(790-1165^{\circ} \mathrm{C}\right)$ but in general, the coarse-grained and fine-grained peridotites suggest deeper and shallower provenance depth, respectively. Olivine
\end{abstract}

grain size in the fine-grained peridotites depends on the size and volume fraction of the pyroxene grains, which is consistent with pinning of olivine grain growth by pyroxenes as second-phase particles. In the coarse-grained peridotites, well-developed olivine crystal-preferred orientation (CPO) is characterized by orthorhombic and [100]-fiber symmetries, and orthopyroxene has a coherent CPO with that of olivine, suggesting their coeval deformation by dislocation creep at high temperature. In the fine-grained microstructures, along with the weakening of the fabric strength, olivine CPO symmetry exhibits a shift towards [010] fiber and the [010] and [001] axes of orthopyroxene are generally distributed subparallel to those of olivine. These data are consistent with deformation of olivine in the presence of low amounts of melts and the precipitation of orthopyroxenes from a melt phase. The bulk CPO of clinopyroxene mimics that of orthopyroxene via a topotaxial relationship of the two pyroxenes. This observation points to a melt-related origin of most clinopyroxenes in the Oran mantle xenoliths.

The textural and geochemical record of the peridotites are consistent with interaction of a refractory harzburgite pro- 
tolith with a high-Mg no. melt at depth (resulting in the formation of coarse-grained clinopyroxene-rich lherzolite and wehrlite) and with a low-Mg no. evolved melt in the shallow subcontinental lithospheric mantle (forming fine-grained harzburgite). We propose that pervasive melt-peridotite reaction - promoted by lateral and/or near-vertical mantle flow associated with lithospheric tearing - resulted in the synkinematic crystallization of secondary lherzolite and wehrlite and had a key effect on grain size reduction during the operation of the Tell-Rif STEP fault. Melt-rock reaction and secondary formation of lherzolite and wehrlite may be widespread in other STEP fault systems worldwide.

\section{Introduction}

Slab edges are necessary ingredients of plate tectonics, and vertical tearing along the lithosphere at the termination of subduction trenches is a geometric consequence that enables the subduction to continue (e.g., Wilson, 1965; Millen and Hamburger, 1998; Govers and Wortel, 2005; Nijholt and Govers, 2015). A subduction-transform edge propagator (STEP) fault is the locus of continual lithospheric tearing at slab edges, which allows subduction of one part of a tectonic plate, while the juxtaposed part remains at the surface (Govers and Wortel, 2005; Nijholt and Govers, 2015). The evolution of the subduction zone along STEP faults results in sharp changes in the lithospheric and crustal thickness, which trigger lateral and/or near-vertical mantle flow associated with lithospheric tearing (e.g., Mancilla et al., 2015; Menant et al., 2016). Upwelling melts that form in this process are likely channelized by the translithospheric STEP faults and may lead to intense melt-rock reaction in the shallow subcontinental lithospheric mantle (SCLM).

In terms of modal composition, melt-rock reaction processes that occur at shallow mantle depths result in a lithological variation trending from refractory peridotites towards lherzolites with a high clinopyroxene/orthopyroxene modal ratio, eventually forming wehrlite (e.g., Peslier et al., 2002; Parkinson et al., 2003; Ionov et al., 2005; Soustelle et al., 2009; Lambart et al., 2012; Bodinier and Godard, 2014; Varas-Reus et al., 2016; Marchesi et al., 2017). The microstructure of such olivine- and clinopyroxene-rich SCLM peridotites usually indicates syn- to post-kinematic meltrock reactions (e.g., Tommasi et al., 2004, 2008; Morales and Tommasi, 2011; Zaffarana et al., 2014; Kourim et al., 2015). While wehrlite and related peridotite lithologies are frequent in the shallow SCLM, the impact of STEP fault in their formation in subduction environments is poorly understood. The western Mediterranean, however, provides a natural laboratory to study the relationship between lithosphere tearing along a STEP fault and its relationship with wehrlitization of the shallow SCLM.
The Betic-Rif orogen has been proposed to form during the westward retreat of the western Mediterranean subduction system (Lonergan and White, 1997; Gutscher et al., 2002; Booth-Rea et al., 2007). Beneath the Betics, a sharp and prominent lithospheric step at the termination of the Iberian lithosphere is interpreted as a near-vertical STEP fault structure associated with lateral lithospheric tearing (Mancilla et al., 2015, 2018). Deformation pattern and seismic anisotropy signal of mantle xenoliths from the eastern Betics indicate steeply dipping foliation and subhorizontal lineations in the shallow SCLM, which are consistent with WSW tearing of the subducted south Iberian margin lithosphere along the STEP fault (Hidas et al., 2016a). Moreover, in the same volcanic field, wehrlite lithologies are interpreted as an interaction with $\mathrm{SiO}_{2}$-undersaturated magmas, similar to the alkali basalts that host the mantle xenoliths (Marchesi et al., 2017). The Oran volcanic field is situated on the northern margin of the African plate and its SCLM records processes related to slab edge delamination and asthenospheric mantle upwelling coupled to the rapid westward retreat of the subduction arc system along the Tell-Rif STEP fault, predating the late-most Miocene development of the Betic STEP fault in the southeastern Betics (Booth-Rea et al., 2007; Garcia-Castellanos and Villasenor, 2011; Platt et al., 2013; van Hinsbergen et al., 2014; Chertova et al., 2014a, b).

The Plio-Pleistocene basaltic volcanism in the Oran volcanic field transported a large number of mantle xenoliths to the surface, mostly in the Aïn Témouchent volcanic complex. Earlier works on the peridotite suite have shown that the SCLM records metasomatic events in the shallow spinel and plagioclase facies due to channeling of reactive alkaline magmas in ductile shear zones (Zerka et al., 2002; Lahmer et al., 2018). However, due to the lack of microstructural data, the reconstruction of deformation mechanisms and the relationship between the melt percolation and deformation along the Tell-Rif STEP fault have remained unexplored. In this study, we provide new microstructural and major element geochemical data on a representative set of mantle peridotites from various localities of the Oran volcanic field. We aim at constraining the physicochemical processes coupled to the lithospheric tearing at a STEP fault in the context of the western Mediterranean geodynamic evolution along the northern margin of the African plate.

\section{Geologic setting and sampling strategy}

The Betic-Tell-Rif orogen in the westernmost Mediterranean (Fig. 1a) was formed during the Miocene collision between the westward-migrating Alboran terrain and the south Iberian and the Maghrebian passive margins in the context of African-Iberian convergence (Jolivet and Faccenna, 2000; Faccenna et al., 2004; Spakman and Wortel, 2004; Booth-Rea et al., 2007). This geodynamic evolution 
resulted in extension due to slab rollback, slab detachment, mantle lithosphere delamination and convective lithospheric thinning (e.g., Platt et al., 2013, and references therein). 3D tomographic imaging of the mantle structure reveals a steeply east-dipping slab under the Strait of Gibraltar with a slab morphology that extends from under the Rif towards the north and then curves eastward under the Betics (e.g., Spakman and Wortel, 2004; Gutscher et al., 2012; Bezada et al., 2013; van Hinsbergen et al., 2014). These works also show a detached slab beneath the Kabylides in northeast Algeria (Spakman and Wortel, 2004; Faccenna et al., 2014; van Hinsbergen et al., 2014), which is interpreted as a part of the Algerian-Tunisian slab separated from the Betic-Rif slab system by STEP faults (Booth-Rea et al., 2018a). The present-day Betic-Rif slab morphology is consistent with the evolution of an initially NW-dipping subduction zone situated southeast of the Balearic Islands in the Oligocene that retreated towards the south and later to the west, after approximately $90^{\circ}$ clockwise rotation, during the Miocene to reach its current position beneath the Strait of Gibraltar (e.g., Royden, 1993; Lonergan and White, 1997; Rosenbaum et al., 2002; Spakman and Wortel, 2004; Chertova et al., 2014a, b; van Hinsbergen et al., 2014). Slab tearing and detachment in the southern part of the slab are associated with the rapid westward retreat of the subduction system (e.g., Roure et al., 2012; Abbassene et al., 2016; Chazot et al., 2017) that created a STEP fault parallel to the north African margin (Mauffret et al., 2004; Medaouri et al., 2014; Chertova et al., 2014a, and references therein).

In this tectonic context, subduction related to intraplate anorogenic magmatism occurred at various places at different geodynamic stages. Neogene to Quaternary volcanism occurred mainly in the southeast Iberia Peninsula, the Maghrebian margins and the present-day Alboran Sea basin (Fig. 1a) (Hoernle et al., 1999; Turner et al., 1999; Duggen et al., 2004, 2005). In the Early to Middle Miocene, the volcanic activity was broadly coeval with extension and subsidence of the Alboran Sea basin and orogenesis in the surrounding Betic-Tell-Rif mountain belt (Lonergan and White, 1997; Comas et al., 1999; Jolivet and Faccenna, 2000; Booth-Rea et al., 2007). Middle to late Miocene tholeiitic through calcalkaline volcanic rocks typical of subduction arc magmatism crop out across the central and eastern Alboran Sea basin (Fig. 1a), on the Alboran Island and in coastal volcanic complexes at the margins of the eastern Betics and the Maghrebides (Fig. 1a) (Turner et al., 1999; Duggen et al., 2004, 2005, and references therein). Actually, the eastern Alboran basin basement is formed by a submerged well-developed volcanic arc (Booth-Rea et al., 2018b; Gómez de la Peña et al., 2018). Meanwhile, at the west Maghrebian and southeast Iberian continental margins, this late Miocene magmatism was coeval to extensional collapse and thinning of the previously thickened orogenic crust (e.g., Booth-Rea et al., 2012; Giaconia et al., 2014; Jabaloy-Sánchez et al., 2015; Azdimousa et al., 2019) and loss of its SCLM root (Duggen et al., 2003; Mancilla et al., 2015). This process is defined as edge delamination by Duggen et al. (2003). Late Miocene to Pliocene topographic uplift and coeval Si-K-rich magmatism and Quaternary alkali basalts in the southeast Iberian Peninsula and the Maghrebian margins have been related to asthenospheric mantle upwelling after late Miocene edge delamination (Duggen et al., 2003, 2005, 2008) and/or earlier slab break-off in the Algerian-Riphean margin (Spakman and Wortel, 2004; Chazot et al., 2017). Mantle xenoliths in Plio-Quaternary alkali basalts have been interpreted to have registered part of this tectonic evolution in the mantle underlying the Betics, preserving the originally subvertical tectonic foliation (Hidas et al., 2016a) probably related to mantle flow during slab tearing along the Betic STEP (Mancilla et al., 2015, 2018).

The Oran volcanic field in northwest Algeria is dominated by Miocene to Plio-Pleistocene calc-alkaline and alkaline volcanic rocks (Fig. 1b) (Louni-Hacini et al., 1995; Coulon et al., 2002; Bendoukha et al., 2009). The volcanic rocks crosscut and overlie the Tell sedimentary nappes overthrust during the Miocene on the northern part of the African plate (Coulon et al., 2002). The alkaline lavas contain a large number of mantle xenoliths (Zerka et al., 2002; Lahmer et al., 2018, and references therein). In this study, we present mantle xenoliths from two localities. Samples with label SOU have been collected in the $2.1 \mathrm{Ma}$ lava flows at the Oued Abdellah beach of Souahlia $\left(35^{\circ} 5^{\prime} 45.58^{\prime \prime} \mathrm{N}\right.$, $1^{\circ} 52^{\prime} 33.23^{\prime \prime} \mathrm{W}$ ), whereas those with labels DZ (Djebel Dzioua; $35^{\circ} 17^{\prime} 21.36^{\prime \prime} \mathrm{N}, 1^{\circ} 14^{\prime} 43.71^{\prime \prime} \mathrm{W}$ ), GU (Djebel Gueriane; $35^{\circ} 11^{\prime} 28.80^{\prime \prime} \mathrm{N}, 1^{\circ} 12^{\prime} 27.00^{\prime \prime} \mathrm{W}$ ) and HAM (Hammar E'Zohra; $35^{\circ} 15^{\prime} 42.81^{\prime \prime} \mathrm{N}, 1^{\circ} 8^{\prime} 41.65^{\prime \prime} \mathrm{W}$ ) are from the 1.3-0.8 Ma basaltic flows in the Aïn Témouchent massif (Fig. 1b). The 25 selected samples (7 DZ, 4 GU, 11 HAM and 3 SOU; Table 1) represent all textural and lithological varieties that occurred in a given outcrop.

\section{Analytical methods}

\subsection{Sample preparation}

Mantle xenoliths from the Oran volcanic field are fresh but their impregnation by fast-acting adhesives and/or epoxy under vacuum was usually necessary before and during thin section preparation. Most xenoliths display no penetrative macroscopic foliation and/or lineation; thus, thin sections were cut at random orientations. In the few samples where foliation and lineation are observable, thin sections were cut perpendicular to foliation and parallel to lineation; the latter is defined by elongated spinels and orthopyroxene porphyroclasts (stretching lineation). Standard petrographic thin sections were ground to a thickness of approximately $150 \mu \mathrm{m}$ and were polished using diamond paste with 3 and $1 \mu \mathrm{m}$ grain sizes. Final surface of the thin sections was achieved after 


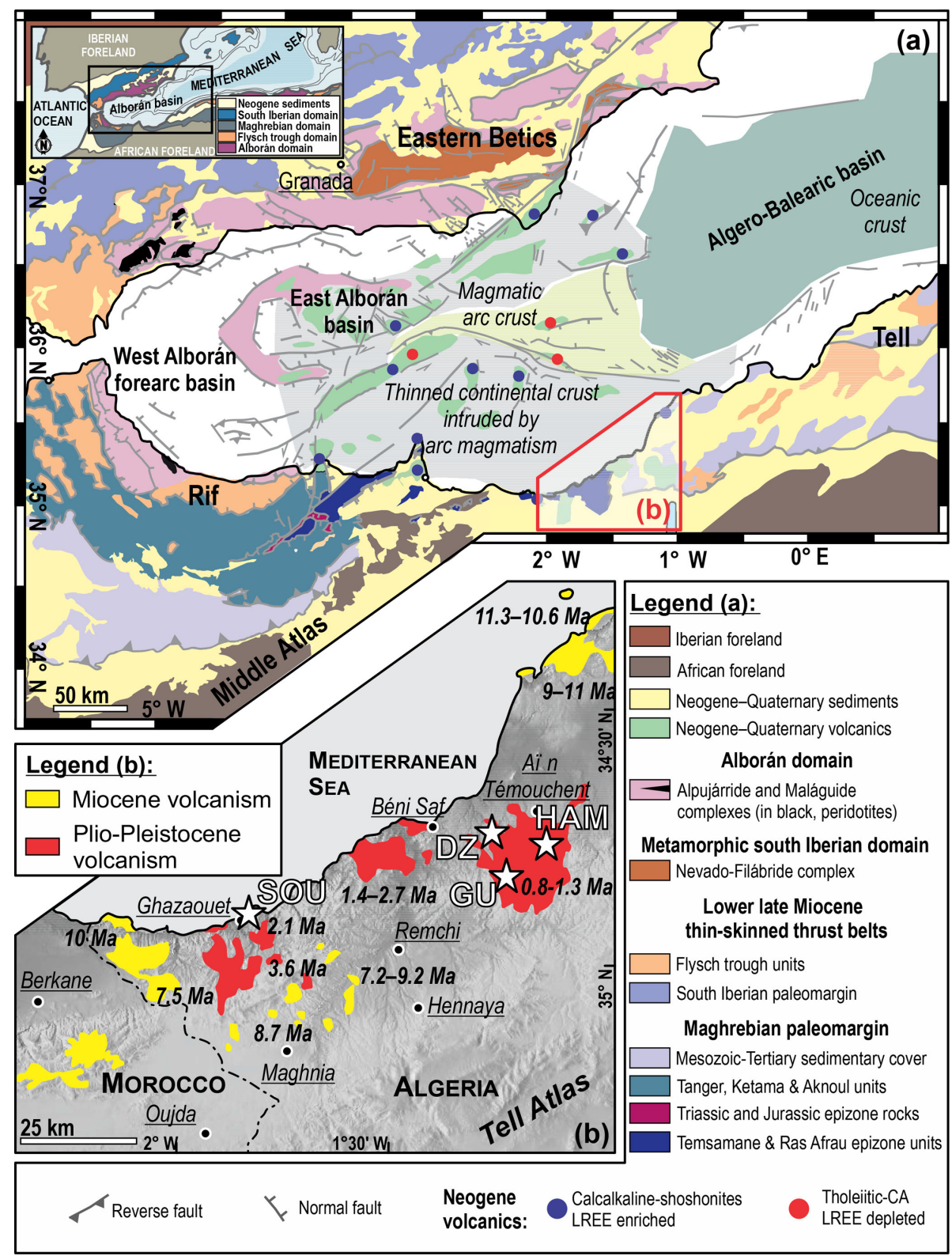

Figure 1. (a) Simplified geological map of the westernmost Mediterranean, showing the main tectonic domains of the Betic-Rif orogenic belt with the areas of oceanic crust, magmatic arc and thin continental crust in the Alboran basin (modified after Booth-Rea et al., 2007, and references therein). The area in a red frame indicates the Oran volcanic field, and it is enlarged in panel (b). (b) Schematic map of the Oran volcanic field showing the occurrences of Miocene and Plio-Pliocene volcanic rocks. Italic numbers correspond to the age of volcanism after Maury et al. (2000) and Duggen et al. (2005). White stars indicate the location of the studied mantle xenoliths with the prefix of the sample labels as DZ (Djebel Dzioua), GU (Djebel Gueriane), HAM (Hammar E'Zohra) and SOU (Souahlia).

45 min of chemical and mechanical polishing using Buehler MasterMet colloidal silica polishing suspension.

\subsection{Microstructural analyses}

For electron backscatter diffraction (EBSD) analyses, the uncoated thin sections were mounted with conductive carbon tape to reduce charging. Analyses were carried out at high vacuum (in the range of $10^{-5}$ mbar) using a Zeiss EVO MA
15 SEM equipped with Oxford Instruments Nordlys Nano EBSD detector and AZtec v. 3.1 data acquisition software (Oxford/HKL) at the Instituto Andaluz de Ciencias de la Tierra (IACT, Armilla, Granada, Spain). Instrumental settings were $17 \mathrm{kV}$ acceleration voltage, $24 \mathrm{~mm}$ working distance, probe current of $0.5-1.0 \mathrm{nA}$, using Agar Scientific tungsten filament as a source of electrons. Acquisition conditions in the EBSD software module were $4 \times 4$ binning and 
Table 1. Summary of petrography, estimated temperatures, modal composition and calculated microstructural parameters in the Oran mantle xenoliths.

\begin{tabular}{|c|c|c|c|c|c|c|c|c|c|c|c|c|c|c|c|c|c|c|c|c|}
\hline \multirow[t]{3}{*}{ Sample } & \multirow[t]{3}{*}{$\begin{array}{l}\text { Lithology } \\
\text { (fabric) }^{\mathrm{a}}\end{array}$} & \multicolumn{6}{|c|}{$\begin{array}{c}\text { Estimated } \\
\text { temperature }\left({ }^{\circ} \mathrm{C}\right)^{\mathrm{b}}\end{array}$} & \multirow{2}{*}{\multicolumn{6}{|c|}{$\begin{array}{c}\text { Modal } \\
\text { composition (\%) }\end{array}$}} & \multirow{2}{*}{\multicolumn{3}{|c|}{$\begin{array}{l}\text { Area-wtd mean } \\
\text { grain size }(\mathrm{mm})\end{array}$}} & \multirow{2}{*}{\multicolumn{4}{|c|}{$\begin{array}{c}\text { Calculated } \\
\text { parameters }^{\mathrm{c}}\end{array}$}} \\
\hline & & \multicolumn{3}{|c|}{ Core } & \multicolumn{3}{|c|}{ Rim } & & & & & & & & & & & & & \\
\hline & & $T_{\mathrm{Ca}-\mathrm{Opx}}$ & $T_{\mathrm{Al}-\mathrm{Opx}}$ & $T_{\text {solv }}$ & $T_{\mathrm{Ca}-\mathrm{Opx}}$ & $T_{\mathrm{Al}-\mathrm{Opx}}$ & $T_{\text {solv }}$ & $\mathrm{Ol}$ & Opx & $\mathrm{Cpx}$ & Spl & Amp & Plag & $\mathrm{Ol}$ & Opx & $\mathrm{Cpx}$ & $\mathrm{BA}$ & $M_{\mathrm{Ol}}$ & $M_{\mathrm{Opx}}$ & $M_{\mathrm{Cpx}}$ \\
\hline DZ-002 & $\mathrm{HZB}(\mathrm{CG})$ & 950 & 1021 & 1034 & 1028 & 1002 & 1093 & 77.0 & 17.7 & 4.8 & 0.6 & & & 1.4 & 1.3 & 0.5 & 0.47 & 0.32 & 0.27 & 0.05 \\
\hline$D Z-003^{d}$ & $\mathrm{LHZ}(\mathrm{CG})$ & 1087 & 955 & 1086 & 1108 & 991 & 1060 & 84.4 & 7.9 & 7.3 & 0.5 & & & 1.5 & 1.5 & 0.5 & 0.52 & 0.33 & 0.31 & 0.12 \\
\hline DZ-004 & HZB (CG) & & & & & & & 87.3 & 11.1 & 1.3 & 0.2 & & & 1.5 & 1.5 & 0.4 & 0.77 & 0.21 & 0.24 & 0.22 \\
\hline $\mathrm{DZ}-005^{\mathrm{d}}$ & LHZ (CGP) & & & & & & & 86.1 & 6.6 & 6.7 & 0.7 & & & 1.0 & 1.3 & 0.5 & 0.74 & 0.27 & 0.36 & 0.06 \\
\hline DZ-007 & HZB (CGP) & 1023 & 987 & 999 & 967 & 889 & 989 & 86.6 & 8.5 & 4.4 & 0.6 & & & 1.2 & 1.0 & 0.4 & 0.74 & 0.24 & 0.25 & 0.03 \\
\hline DZ- $009^{d}$ & LHZ (CGP) & 957 & 1063 & 873 & 911 & 924 & 851 & 69.5 & 20.0 & 9.9 & 0.6 & & & 1.2 & 1.8 & 1.2 & 0.79 & 0.19 & 0.15 & 0.14 \\
\hline DZ-010b & LHZ (CGP) & & & & & & & 77.1 & 13.8 & 7.8 & 1.0 & 0.4 & & 0.8 & 1.1 & 0.7 & 0.88 & 0.20 & 0.21 & 0.05 \\
\hline GU-001 & LHZ (CGP) & 1047 & 1163 & 907 & 901 & 890 & 879 & 75.1 & 9.5 & 14.0 & 1.2 & 0.3 & & 1.1 & 2.4 & 0.8 & 0.68 & 0.26 & 0.32 & 0.08 \\
\hline GU-002 & LHZ (EQ) & & & & & & & 89.7 & 4.0 & 6.2 & 0.0 & 0.1 & 0.1 & 0.6 & 0.3 & 0.3 & 0.41 & 0.17 & 0.04 & 0.03 \\
\hline GU-003 & HZB (CGP) & & & & & & & 82.8 & 13.7 & 3.4 & 0.0 & & & 0.8 & 1.8 & 0.4 & 0.68 & 0.27 & 0.29 & 0.09 \\
\hline GU- $007^{\mathrm{d}}$ & HZB (CGP) & & & & & & & 87.4 & 9.1 & 3.1 & 0.3 & & & 1.0 & 1.1 & 0.5 & 0.64 & 0.18 & 0.17 & 0.20 \\
\hline HAM-001 & WHR (CG) & 1043 & 986 & 997 & 1068 & 1048 & 1057 & 71.4 & 4.3 & 23.9 & 0.4 & & & 1.3 & 0.7 & 1.0 & 0.77 & 0.17 & 0.16 & 0.07 \\
\hline HAM-004 & HZB (EQ) & & & & & & & 78.3 & 17.8 & 2.6 & 1.2 & 0.1 & 0.1 & 0.4 & 0.2 & 0.2 & 0.72 & 0.19 & 0.06 & 0.02 \\
\hline $\mathrm{HAM}-005 \mathrm{~b}^{\mathrm{d}}$ & LHZ (FGP) & 949 & 971 & 983 & 939 & 942 & 1017 & 80.1 & 12.5 & 6.6 & 0.6 & 0.0 & 0.2 & 0.8 & 0.8 & 0.4 & 0.65 & 0.12 & 0.03 & 0.03 \\
\hline HAM- $006^{\mathrm{d}}$ & HZB (EQ) & & & & & & & 81.7 & 15.3 & 2.8 & 0.2 & & & 0.5 & 0.3 & 0.2 & 0.37 & 0.12 & 0.03 & 0.05 \\
\hline HAM-007 & HZB (EQ) & & & & & & & 74.0 & 21.8 & 3.4 & 0.8 & & 0.1 & 0.4 & 0.5 & 0.3 & 0.24 & 0.13 & 0.01 & 0.03 \\
\hline HAM-009 & LHZ (FGP) & & & & & & & 69.8 & 19.0 & 9.4 & 1.0 & & 0.8 & 0.6 & 1.6 & 0.4 & 0.72 & 0.09 & 0.08 & 0.02 \\
\hline HAM-011 & HZB (EQ) & & & & & & & 80.8 & 13.0 & 4.7 & 0.5 & 0.6 & 0.4 & 0.4 & 0.3 & 0.2 & 0.35 & 0.18 & 0.01 & 0.02 \\
\hline HAM- $012^{\mathrm{d}}$ & LHZ (EQ) & 939 & 939 & 790 & 979 & 909 & 884 & 83.5 & 10.1 & 5.5 & 0.6 & 0.2 & 0.1 & 0.5 & 0.4 & 0.3 & 0.45 & 0.12 & 0.03 & 0.02 \\
\hline HAM-016 & HZB (EQ) & & & & & & & 81.9 & 13.6 & 1.4 & 3.0 & 0.1 & & 0.6 & 0.3 & 0.2 & 0.67 & 0.20 & 0.05 & 0.04 \\
\hline HAM- $017^{\mathrm{d}}$ & LHZ (EQ) & 945 & 953 & 928 & 992 & 872 & 974 & 79.0 & 14.1 & 6.3 & 0.6 & & & 0.6 & 0.5 & 0.3 & 0.42 & 0.10 & 0.02 & 0.02 \\
\hline HAM-018 & LHZ (EQ) & 985 & 1010 & 842 & 974 & 931 & 909 & 54.1 & 12.2 & 32.4 & 0.0 & 0.2 & 0.2 & 0.3 & 0.4 & 0.4 & 0.37 & 0.03 & 0.01 & 0.01 \\
\hline SOU-001 & LHZ (CGP) & & & & & & & 75.0 & 16.0 & 8.2 & 0.8 & & & 1.0 & 1.0 & 0.4 & 0.55 & 0.37 & 0.29 & 0.06 \\
\hline SOU-002 & LHZ (CG) & 950 & 953 & 977 & 965 & 919 & 956 & 53.2 & 26.3 & 17.5 & 2.9 & 0.1 & & 0.9 & 2.0 & 1.0 & 0.64 & 0.22 & 0.14 & 0.04 \\
\hline SOU-003 & WHR (CG) & - & - & & - & - & & 89.5 & 0.0 & 9.7 & 0.8 & & & 1.3 & 0.2 & 0.7 & 0.39 & 0.21 & & 0.06 \\
\hline
\end{tabular}

a Lithology: HZB, harzburgite; LHZ, lherzolite; WHR, wehrlite/(fabric): CG, coarse granular; CGP, coarse-grained porphyroclastic; FGP, fine-grained porphyroclastic;

EQ, fine-grained equigranular. ${ }^{\mathrm{b}} T_{\mathrm{Ca}-\mathrm{Opx}}: \mathrm{Ca}$ in orthopyroxene $\left( \pm 16^{\circ} \mathrm{C}\right)$, Brey and Köhler $(1990) ; T_{\mathrm{Al}-\mathrm{Opx}}: \mathrm{Cr}-\mathrm{Al}-\mathrm{orthopyroxene}\left( \pm 15^{\circ} \mathrm{C}\right)$, Witt-Eickschen and Seck $(1991)$; $T_{\text {solv }}$ : clinopyroxene-orthopyroxene geothermometer $\left( \pm 16^{\circ} \mathrm{C}\right)$, Brey and Köhler (1990). Dash symbols at SOU-003 wehrlite indicate that thermometers could not be applied in this sample; blank cells are xenoliths without EMPA data. ${ }^{\mathrm{c}}$ BA, BA index of olivine; $M_{\mathrm{Ol}}, M$ index of olivine; $M_{\mathrm{Opx}}, M$ index of orthopyroxene; $M_{\mathrm{Cpx}}, M$ index of clinopyroxene (Skemer et al., 2005). ${ }^{\mathrm{d}}$ Oriented thin section.

low (0) gain with grid steps varied between 17 and $40 \mu \mathrm{m}$ (depending on the grain size), covering most of the sample surface. All major constituent minerals of the rocks were included in the phase list, and the percentage of indexed points in the raw maps typically exceeded $75 \%$. In some xenoliths (samples DZ-005, GU-003, HAM-004, HAM-006, HAM016), the interstitial adhesive used for impregnation has resulted in local charging effect of the thin section surface, reducing the EBSD indexing rate to $40 \%-60 \%$. The obtained data, however, are representative of the entire thin section, and EBSD data from these samples have been included in the database. Post-acquisition data treatment to clean raw maps was carried out following the procedure presented in Soustelle et al. (2010), using the built-in functions of the Oxford/HKL Channel 5 software package.

For further data processing and calculations - carried out on cleaned EBSD datasets - we used the builtin functions of the free MTEX 4.5.2 Matlab toolbox (https://mtex-toolbox.github.io, last access: February 2018; Hielscher and Schaeben, 2008; Bachmann et al., 2010). For the complete database of calculated parameters, see Table S1. Grain boundaries are defined at $12^{\circ}$ minimum misorientation between neighboring pixels (segmentation angle); the correctness of grain definition has been checked in an optical microscope. Low misorientation boundaries in the range of $2-12^{\circ}$ are considered as subgrain boundaries. Several meth- ods have been proposed for strain analysis from EBSD data (see Wright et al., 2011 for a review). In the present study, we characterize intragranular misorientations by the misorientation relative to the mean orientation of a grain (Mis2Mean), which is the deviation in orientation at a measurement point from the mean orientation of the grain to which the point belongs. The spread in orientations within a grain is characterized by the grain orientation spread (GOS), which is the average of the Mis2Mean over the grain. Sharp gradients in misorientations, such as subgrain boundaries, are best visualized by calculating second nearest-neighbor kernel average misorientations (second-order KAM; hereafter KAM2) maps. The KAM2 is the deviation in orientation of a measurement pixel from the average orientation of its nearest 12 neighbors. Here, it is calculated with a cut-off value of $12^{\circ}$ (i.e., segmentation angle used for defining a high-angle boundary). To compare samples to each other, in the analyzed surface we calculate simple averages of KAM2 and Mis2Mean data, and area-weighted averages for GOS and descriptive parameters of grain morphology (e.g., shape, size) to reduce the effect of strain-free small grains. To characterize the symmetry of olivine CPO, we calculated the BA index (Mainprice et al., 2014) based on the equation of BA index = $0.5 \times\left[2-\left[P_{010} /\left(G_{010}+P_{010}\right)\right]-\left[G_{100} /\left(G_{100}+P_{100}\right)\right]\right]$. This parameter considers the point $(P)$ and girdle $(G)$ distribution of [010] and [100] crystallographic axes. For each axis, 
these distributions are calculated from the orientation tensor and its three eigenvalues $\lambda_{1}, \lambda_{2}, \lambda_{3}$ (where $\lambda_{1} \geq \lambda_{2} \geq \lambda_{3}$ and $\lambda_{1}+\lambda_{2}+\lambda_{3}=1$; Vollmer, 1990) as $P=\lambda_{1}-\lambda_{2}$ and $G=2 \times\left(\lambda_{2}-\lambda_{3}\right)$. For a perfect [010]-fiber CPO, the $P$ and $G$ values for [100] and [010] are 0, 1 and 1, 0, respectively, and the BA index is 0 . In the other endmember case, a perfect [100]-fiber CPO, the $P$ and $G$ values for [100] and [010] are 1,0 and 0,1 , respectively; hence, the BA index is 1 . In a perfect orthorhombic fabric, for both [100] and [010], $P$ and $G$ values are 1 and 0 , respectively; thus, the BA index is 0.5 . Note that this index only specifies CPO symmetry but not the position of crystallographic axes with respect to structural elements in the rock (lineation and foliation). Finally, we calculate the strength of CPO (i.e., fabric strength) using the misorientation index ( $M$ index) developed by Skemer et al. (2005). The $M$ index is 0 for random fabric and 1 for a single crystal; in highly deformed samples, its empirical value is approximately 0.45 .

For oriented thin sections, the crystal-preferred orientation (CPO) is shown in the structural reference frame with lineation and pole to the foliation at the E-W and N-S directions of the pole figures, respectively. For randomly cut thin sections, measured CPOs were rotated into a common frame of reference, in which the maximum concentration of olivine [100] and [010] axes is parallel to the E-W and $\mathrm{N}-\mathrm{S}$ directions of the pole figures, respectively. Note that this rotation does not affect the intensity nor the symmetry of the CPO, and it does not influence the relative orientation of crystallographic axes of different mineral phases in a given sample. To avoid overrepresentation of large crystals, we plot CPO for average grain orientations ("one point per grain") instead of individual measurements using the CareWare software package of David Mainprice (http://www.gm.univ-montp2.fr/PERSO/mainprice/W_data/ CareWare_Unicef_Programs/, last access: January 2015).

\subsection{Mineral chemistry}

Quantitative analyses of major element composition of minerals were carried out on a CAMECA SX 100 electron microprobe (EMPA) at the Centro de Instrumentación Científica (CIC) of the University of Granada (Spain). Accelerating voltage was $15-20 \mathrm{kV}$, with a sample current of $10-15 \mathrm{nA}$ and a beam diameter of $5 \mu \mathrm{m}$. Counting time for each element was 10-30 s. Natural and synthetic silicate and oxide standards were used for calibration and the ZAF correction. The results of major element analyses of minerals are listed in Table S1 in the Supplement.

\section{Petrography}

\subsection{Lithologies}

The studied mantle xenoliths from Oran are typically 5$7 \mathrm{~cm}$ in diameter, and the majority of the samples are from the spinel facies. Rare plagioclase (typically $<0.5 \%$, except for $0.8 \%$ in xenolith HAM-009) occurs mostly at the HAM locality in the Aïn Témouchent massif (Table 1). The majority of the mantle xenoliths show a modal compositional trend from fertile lherzolite to olivine-rich harzburgite, and the refractory lithologies - such as olivine-rich lherzolite and harzburgite - are the most abundant (Fig. 2a). There is a population, however, that reflects anomalously high clinopyroxene content and can be classified as clinopyroxene-rich lherzolite and wehrlite ( $<10 \%$ of the samples) (Fig. 2a).

Irrespective of the locality and the lithology, hydrous phases (mostly amphibole) are also present in low modal amounts $(<0.6 \%)$ (Table 1). Indications for the presence of interstitial glass have also been found, although the current state of preservations of the xenoliths did not allow their further investigation. These petrographic features, the observed lithologies and their abundances are nevertheless consistent with earlier reports from the same volcanic field (e.g., Zerka et al., 2002; Lahmer et al., 2018).

\subsection{Textures and microstructures}

The most striking textural feature of the studied xenoliths from Oran is the gradual decrease and homogenization of the grain size from $1.5-2.0$ to $0.3 \mathrm{~mm}$ due to the increasing amount of fine-grained, dispersed pyroxenes \pm olivine in the fabric (Fig. 2b, Table 1). Based on the overall grain size and the bimodal or homogeneous grain size distribution of the silicate phases, we group the xenoliths into four textural types. The two endmembers are characterized by rather homogeneous grain size distribution accompanied by severalmillimeter large olivine and orthopyroxene in the coarse granular (six samples; $24 \%$ ) and submillimetric olivine and pyroxenes in the equigranular texture (nine samples; $36 \%$ ) (Fig. 2b). Probably the latter texture type was considered as a mylonite in earlier works from the Oran (e.g., Zerka et al., 2002). The transition is marked by textures that contain large orthopyroxene and, rarely, clinopyroxene crystals surrounded by a significantly finer-grained matrix composed of olivine and pyroxenes. Based on the average grain size of olivine in these transitional textures, we distinguish coarsegrained porphyroclastic (olivine $>0.8 \mathrm{~mm}$ area-weighted average grain size; eight samples, $32 \%$ ) and fine-grained porphyroclastic texture types (olivine $<0.8 \mathrm{~mm}$ area-weighted average grain size; two samples, $8 \%$ ) (Fig. 2b). Hereafter, we address the coarse granular and the coarse-grained porphyroclastic textures as coarse-grained and the fine-grained porphyroclastic and equigranular textures as fine-grained rocks (Fig. 2b).

In the coarse-grained rocks, large olivines show moderate intracrystalline deformation features. They contain widely spaced subgrain boundaries perpendicular to the weak elongation direction of the minerals and have an undulose extinction in crossed-polarized light optical microscope (Fig. 3ac). The grain boundaries of large olivine grains are typically 

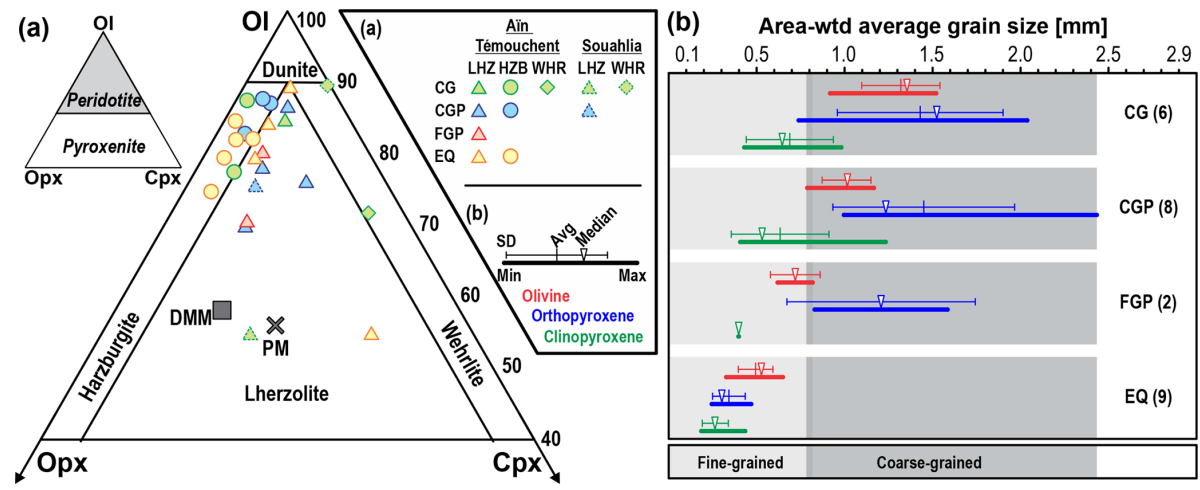

Figure 2. (a) The modal composition of the Oran mantle xenoliths in a Streckeisen diagram for ultramafic rocks (Streckeisen, 1976). DMM: depleted mid-ocean ridge basalt (MORB) mantle; PM: primitive mantle (after McDonough and Sun, 1995; Workman and Hart, 2005). (b) Distribution of area-weighted mean grain size of olivine, orthopyroxene and clinopyroxene in the Oran mantle xenoliths. Horizontal thick bars are the full range of grain sizes (from minimum to maximum) in a given textural group, thinner horizontal bars show the average with standard deviation, and white triangles indicate the median value. Numbers in brackets give the number of xenoliths in a given textural group. CG: coarse granular; CGP: coarse-grained porphyroclastic; FGP: fine-grained porphyroclastic; EQ: fine-grained equigranular; LHZ: lherzolite; HZB: harzburgite; WHR: wehrlite. See text for further details.

lobate but dynamic recrystallization into strain-free neoblasts is rarely observed (Fig. 3a-b). Rather than a mantle around porphyroclasts - typical for dynamic recrystallization - the fine-grained olivine fraction occurs locally along interstitial patches intermixed with fine-grained ortho- or clinopyroxene (Fig. 3b). When olivine is intermixed with pyroxenes, its grain size is significantly smaller than in pyroxene-free areas (Fig. 3b). In the fine-grained rocks, olivine contains negligible intragranular misorientations and generally lacks subgrain boundaries (Fig. 3d-f). Grains are often polygonal with straight or gently curved grain boundaries meeting at $120^{\circ}$ triple junctions, particularly in the equigranular texture (Fig. 3e-f).

Pyroxenes are present in two remarkably different textural positions. On the one hand, orthopyroxene can form porphyroclasts up to $0.5 \mathrm{~cm}$ in diameter slightly elongated in shape (Fig. 3b), with aspect ratios up to $4: 1$. These porphyroclasts frequently contain exsolution lamellae of clinopyroxene in orthopyroxene (Fig. 3a) and have strongly curved, sutured grain boundaries (Fig. 3b) that contain fine-grained olivine in their embayments (Fig. 3b,e). Dynamic recrystallization into strain-free neoblasts is present but is not common. Clinopyroxene may also form large crystals that are not porphyroclasts but aggregates of several millimetric crystals in elongated patches in the plane of the foliation (e.g., xenoliths GU-001, HAM-001, HAM-009; Fig. S1 in the Supplement). Large pyroxenes are rarely observed in the equigranular texture. On the other hand, both pyroxenes occur as a finegrained, elongated (with breadth $<100 \mu \mathrm{m}$ ) mineral fraction free from petrographic signs of intracrystalline lattice distortion and usually dispersed in the rocks without showing textural preference to porphyroclasts. These small pyroxenes are highly irregular in shape with convex grain boundaries and form diffuse bands along olivine-olivine grain boundaries or have cusp-like termination at triple junctions (Fig. 3e). Small pyroxenes are rare in the coarse-grained rocks and they are the most abundant in the equigranular texture. Small orthopyroxene and clinopyroxene are generally present with a proportion ranging from $80: 20$ to $60: 40$ in a given xenolith, respectively, and they typically occur in patches rich in small olivines that are heterogeneously intermixed with either clino- or orthopyroxene (Fig. 3e). Phase mixing between the two pyroxenes is rare in such domains. In some clinopyroxene-rich depleted lherzolite (e.g., DZ-003), the fine-grained clinopyroxene occurs as a rim on orthopyroxene porphyroclasts with irregular phase boundaries and identical crystallographic orientation of the two pyroxenes (Fig. 3b). These clinopyroxenes also host a large amount of primary fluid/melt inclusions.

Dark brown, millimetric spinel crystals are typically elongated in the plane of the foliation parallel to the lineation, or less commonly, they appear with holly-leaf structures filling interstices between silicates. A minor, fine-grained spinel fraction $(<200 \mu \mathrm{m}$ in diameter) occurs together with fine-grained pyroxenes at the grain boundaries of olivine. Plagioclase, if present, is fine grained $(<200 \mu \mathrm{m}$ in diameter) and forms polygonal crystals surrounding large spinel. Rarely, it is observed as an interstitial phase intermixed with fine-grained pyroxenes. These occurrences and the observed modal contents of plagioclase are nevertheless compatible with dominantly subsolidus origin of plagioclase at the expense of spinel (e.g., Rampone et al., 1993; Borghini et al., 2010, and references therein). Amphibole, if present, shows no textural variability and occurs as fine-grained $(50-100 \mu \mathrm{m}$ in diameter) interstitial crystals. 

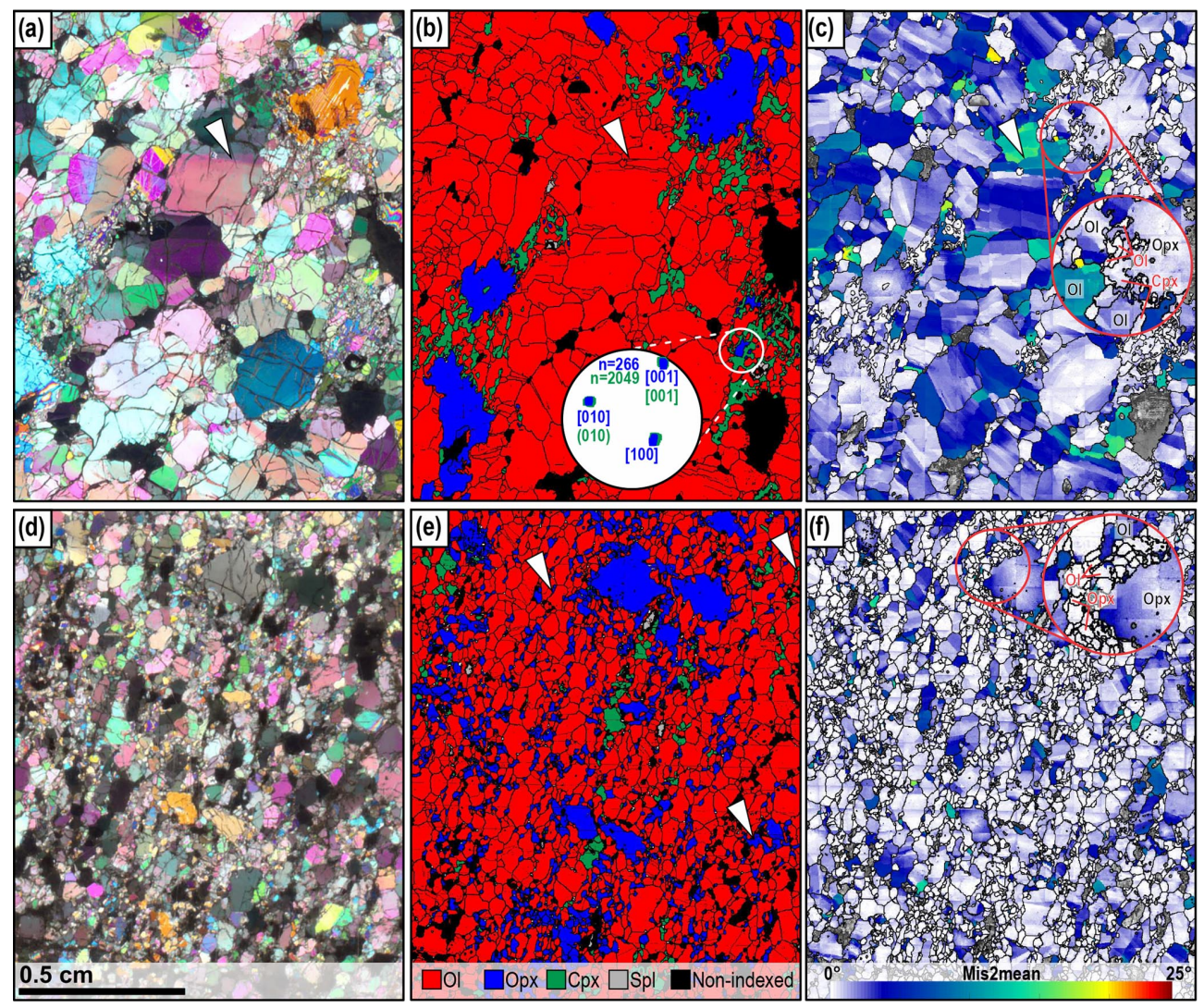

Figure 3. Representative textures of a coarse-grained (a-c) and a fine-grained (d-f) mantle xenolith from Oran (xenoliths DZ-003 and HAM017, respectively). In each row, the same area is shown in cross-polarized optical images (a, d), EBSD phase maps (b, e) and misorientation to the mean orientation of the grain (Mis2Mean) maps (c, $\mathbf{f}$; units are in degrees). White triangles in panels (a-c) point at a subgrain boundary in olivine and in panel (e) point at small, irregularly shaped pyroxenes at olivine-olivine grain boundaries and triple junctions. The inset in panel (b) shows the crystallographic orientation of an orthopyroxene crystal rimmed by clinopyroxene in lower-hemisphere equal-area projection of the main crystallographic axes ( $n$ denotes the number of orientations plotted for each crystal). Note that images in the figure are cropped out from EBSD maps; see Fig. S1 in the Supplement for the entire maps.

\subsection{Crystal-preferred orientation (CPO)}

In all xenoliths from Oran, olivine displays a well-developed $\mathrm{CPO}$ with variable intensities and pattern symmetries in the function of texture. Most coarse-grained rocks are characterized by orthorhombic and [100]-fiber olivine symmetries (BA indices of 0.5-0.9) and moderate olivine fabric strength ( $M$ indices of 0.17-0.37) (Fig. 4). Although olivine CPO in the majority of the equigranular samples can be also classified as orthorhombic, we observe a minor yet characteristic shift towards the field of [010]-fiber pattern (BA indices $<0.45$; Fig. 4). The fabric strength of these latter samples ( $M$ indices 0.03-0.18) is also weaker than that of the coarse-grained rocks. The fine-grained porphyroclastic samples show [100]-fiber CPO symmetries similar to the coarsegrained rocks but they are accompanied with $\mathrm{CPO}$ intensities typical for equigranular textures ( $M$ index $<0.12$; Fig. 4$)$. Finally, the wehrlite from Souahlia is characterized by a CPO symmetry similar to the equigranular samples (BA index of 0.39 ) but with somewhat stronger fabric ( $M$ index of 0.22 )
(Fig. 4). In the oriented thin sections, the maximum density of [100] axes is subparallel to the stretching lineation and the [010] axes show a maximum normal to the plane of the foliation. In the [100]-fiber CPO symmetries, typical for many coarse-grained xenoliths, the dispersion of [010] axes form a girdle in a plane normal to the [100] maximum and the [001] axes either form a weak girdle parallel to the distribution of [010] axes or are at high angle to the lineation in the plane of the foliation (Fig. 5a). In the orthorhombic CPO symmetries that show tendency towards [010]-fiber pattern, typical for some fine-grained xenoliths, we observe a strong maximum of [010] perpendicular to the foliation and a very weak girdle of [100] and [001] axes in the plane of the foliation (e.g., sample HAM-007 in Fig. 5b). Irrespective of the CPO symmetry, the concentration of [100] axes is always stronger than that of the [001] (Fig. S1). The observed olivine CPO patterns in the Oran xenoliths are the most abundant ones among those reported from mantle xenoliths and massive peridotites 


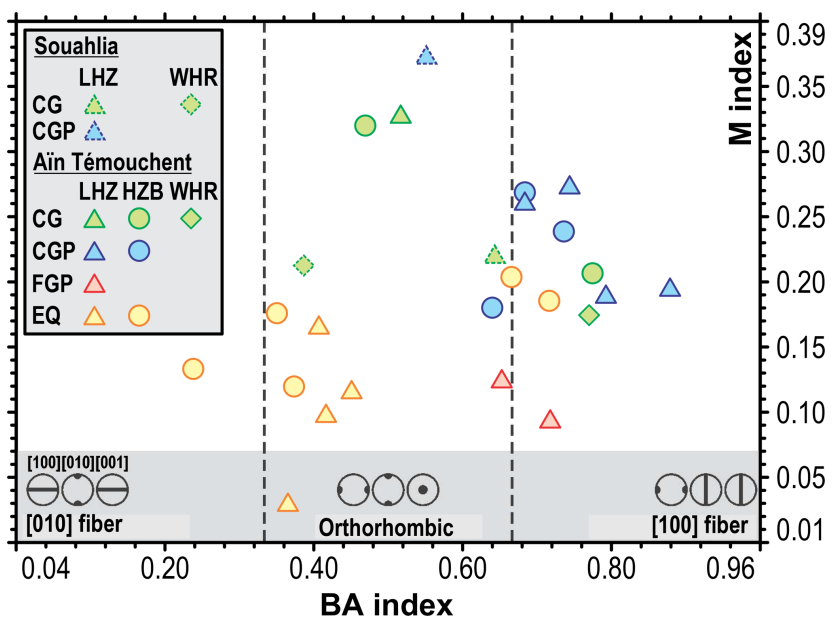

Figure 4. BA index of olivine in the function of olivine fabric strength (expressed as $M$ index). Vertical dashed lines show the guidelines for differentiating [010]-fiber, orthorhombic and [100]fiber CPO symmetries. Abbreviations in the legend are the same as for Fig. 2.

from different geodynamic environments worldwide (Tommasi et al., 2000; Tommasi and Vauchez, 2015).

The CPO of orthopyroxene in most samples is more dispersed than that of olivine, and the fabric strength and the alignment of crystallographic axes with respect to structural elements show a strong correlation with texture type. In the coarse-grained xenoliths, the [001] axes of orthopyroxene are subparallel to the [100] axes of olivine and hence the stretching lineation (Fig. 5a). This is also confirmed on elongated porphyroclasts, where [001] axes are parallel to the elongation direction of the grains. In addition, the [100] axes of orthopyroxenes also display weak alignment with the [010] axes of olivine, and they are distributed at the pole of the foliation in the oriented thin sections. In the coarse-grained rocks, orthopyroxene has a moderate fabric strength ( $M$ index of 0.13-0.36), which is positively correlated to that of olivine (Table 1). In the fine-grained rocks - particularly in the equigranular samples - the main crystallographic axes of orthopyroxene are generally distributed subparallel to those of olivine (e.g., [010 $]_{\mathrm{OI}}||[010]_{\mathrm{Opx}}$ in xenoliths HAM-007 and HAM-018 in Fig. 5b). Such subparallel distribution is characteristic mostly for [010] and, less frequently, [100] or [001] axes. The fabric strength of orthopyroxene is also weak in these samples, with $M$ indices ranging from 0.01 to 0.08 (Table 1).

The crystallographic axes of clinopyroxene are typically distributed subparallel to that of orthopyroxene (Fig. 5), which has also been confirmed locally on a grain-by-grain basis earlier in Fig. 3b. Note that significant misindexing of these two phases have not been observed in the EBSD maps. The fabric of clinopyroxene is typically weaker than that of orthopyroxene, irrespective of the texture type (Fig. 5) and
- apart from three coarse-grained samples - the $M$ index of clinopyroxene ranges from 0.01 to 0.11 (Table 1).

To characterize the rotation axes accommodating lowangle $\left(2-12^{\circ}\right)$ misorientations in olivine and orthopyroxene, we made empirical subsets of large ( $>400 \mu \mathrm{m}$ equivalent diameter) and small grains $(<400 \mu \mathrm{m}$ equivalent diameter) that allow for differentiating the two remarkably different pyroxene populations presented in the petrography in mantle xenoliths representative of each textural group (Fig. 6). In olivine, rotation axes usually show $\langle 0 \mathrm{vw}\rangle$ orientations irrespective of the grain size but maxima around [010] become stronger with grain refinement, and low-angle misorientation is dominantly accommodated around this axis in the small grain fraction of equigranular xenoliths (Fig. 6a). In orthopyroxene, lowangle misorientations are accommodated around [010] axes in large grains but in the small grains rotation around [001] also appears and sometimes becomes dominant, particularly in fine-grained xenoliths (Fig. 6b).

\section{Mineral chemistry and geothermometry}

\subsection{Mineral major element composition}

The results of EMPA analyses are provided in Table S1 in the Supplement. The average olivine $\mathrm{Mg}$ no. $-\mathrm{Mg}$ no. $=100 \times \mathrm{Mg} /\left(\mathrm{Mg}+\mathrm{Fe}^{2+}\right)$ in atomic per formula units in the Oran xenoliths typically plots in the range of 89.490.8 regardless of the texture type or lithology, except for an equigranular, clinopyroxene-rich lherzolite HAM-018 where it is anomalously low (86.1, Fig. 7a). The average values show, however, significant standard variations particularly in the fine-grained rocks and in the wehrlites (Fig. 7a). The average $\mathrm{NiO}$ content in olivine typically ranges from $0.34 \mathrm{wt} \%$ to $0.42 \mathrm{wt} \%$ without correlation to texture type, but lower values are more often in wehrlite and clinopyroxene-rich lherzolite (Table S1). We observe no significant differences in major element composition of olivine cores and rims (Table S1).

The average spinel $\mathrm{Cr}$ no. $-\mathrm{Cr}$ no. $=100 \times \mathrm{Cr} /(\mathrm{Cr}+\mathrm{Al})$ in atomic per formula units - and $\mathrm{Mg}$ no. encompass a wide range from 9.0 to 55.0 and 58.7 to 78.1 , respectively, and show no correlation to texture type or lithology. We detect no systematic differences between cores and rims either, but in some samples, the cores are up to $5 \mathrm{wt} \%$ richer in $\mathrm{Al}_{2} \mathrm{O}_{3}$ and poorer in $\mathrm{Cr}_{2} \mathrm{O}_{3}$ than the corresponding rims (Table $\mathrm{S} 1$ ). Covariation between olivine $\mathrm{Mg}$ no. and spinel $\mathrm{Cr}$ no. is normally observed in spinel peridotites from different tectonic settings (Arai, 1994). Most xenoliths from Oran plot within the field of the olivine-spinel mantle array and are distributed along the typical partial melting trend of a fertile mantle source, being residues of relatively high degrees of partial melting (10\%-25\%; Fig. 7a). The only exception is sample HAM-018, which plots to the right of this field due to its low olivine Mg no. (Fig. 7a), similarly to wehrlites from the east- 


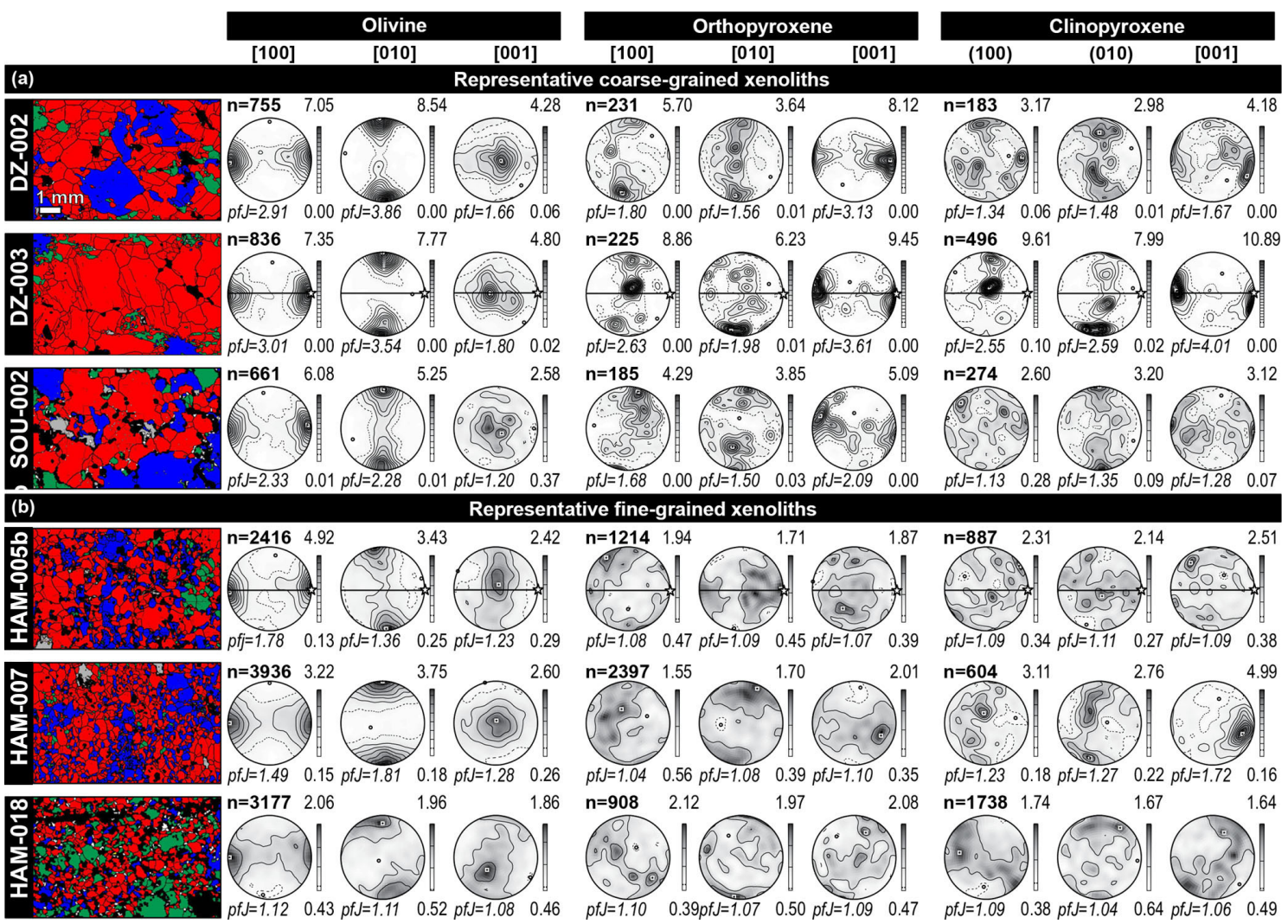

Figure 5. CPO of olivine, orthopyroxene and clinopyroxene in representative coarse-grained (a) and fine-grained mantle xenoliths (a) from the Oran volcanic field. For the full dataset, see Fig. S1 in the Supplement. Pole figures are lower-hemisphere, equal-area stereographic plots using one average measurement per grain ("one point per grain") with contours at 0.5 multiples of a uniform distribution. In oriented thin sections of DZ-003 and HAM-005b, the horizontal line denotes the foliation, and a white star corresponds to the lineation. The CPO in other xenoliths has been rotated in this reference frame in order to make the comparison possible. See text for further details on this rotation. $N$ : number of measured grains; pfJ: scalar measure of the strength of the axis orientation in the pole figure. To the left of the pole figures, the characteristic microstructure is shown for each sample as the EBSD phase map (color coding is the same as in Fig. 3) with the same magnification.

ern Betics (e.g., Marchesi et al., 2017), as well as strongly metasomatized peridotites and ultramafic cumulates worldwide (Arai, 1994).

The average orthopyroxene $\mathrm{Mg}$ no. ranges from 89.1 to 91.9, except for the sample HAM-018, where we calculate values down to 86.1 (Table $\mathrm{S} 1$ ). The average $\mathrm{Al}_{2} \mathrm{O}_{3}$ $(2.2 \mathrm{wt} \%-5.9 \mathrm{wt} \%)$ and the $\mathrm{CaO}(0.5 \mathrm{wt} \%-1.8 \mathrm{wt} \%)$ in orthopyroxene are not correlated to texture or lithology but, in general, the concentrations tend to be lower in the finegrained rocks and towards the mineral rims.

Regardless of texture and lithology, the average clinopyroxene $\mathrm{Mg}$ no. spans from 88.9 to 93.6, and the $\mathrm{Cr}_{2} \mathrm{O}_{3}$ and $\mathrm{Na}_{2} \mathrm{O}$ contents are typically in the range of $0.82 \mathrm{wt} \%-$ $1.3 \mathrm{wt} \%$ and $0.92 \mathrm{wt} \%-1.59 \mathrm{wt} \%$, respectively (Table S1). The fine-grained rocks tend to have a slightly higher $\mathrm{Mg}$ no. than the coarse-grained rocks, but the ranges overlap. The only exception is the fine-grained sample HAM018 that has an anomalously low $\mathrm{Mg}$ no. (86.8-88.0), and $\mathrm{Cr}_{2} \mathrm{O}_{3}(0.42 \mathrm{wt} \%-0.77 \mathrm{wt} \%)$ and $\mathrm{Na}_{2} \mathrm{O}(0.72 \mathrm{wt} \%-$
$0.94 \mathrm{wt} \%$ ) contents (Table S1). We have not observed any systematic intragranular variation in the major element composition of clinopyroxene.

\subsection{Geothermometry}

We calculated the two-pyroxene solvus $T_{\mathrm{Cpx}-\mathrm{Opx}}$ (Brey and Köhler, 1990) and the Cr-Al-orthopyroxene $T_{\mathrm{Cr}-\mathrm{Al}-\mathrm{Opx}}$ (Witt-Eickschen and Seck, 1991) geothermometers for the core and the rim composition (Table 1; Fig. 7b). The estimated uncertainty given by the authors is $\pm 16^{\circ} \mathrm{C}$ for both methods. In the SOU-003 wehrlite sample, estimating the temperature was not possible due to the lack of geothermometric formulation in clinopyroxene-olivine assemblages (Nimis and Grütter, 2010).

We obtained a wide range of temperatures (790-1165 and $850-1090^{\circ} \mathrm{C}$ from cores and rims, respectively), and the results of the geothermometers are usually strikingly different in the same sample. In general, the rims provide lower tem- 


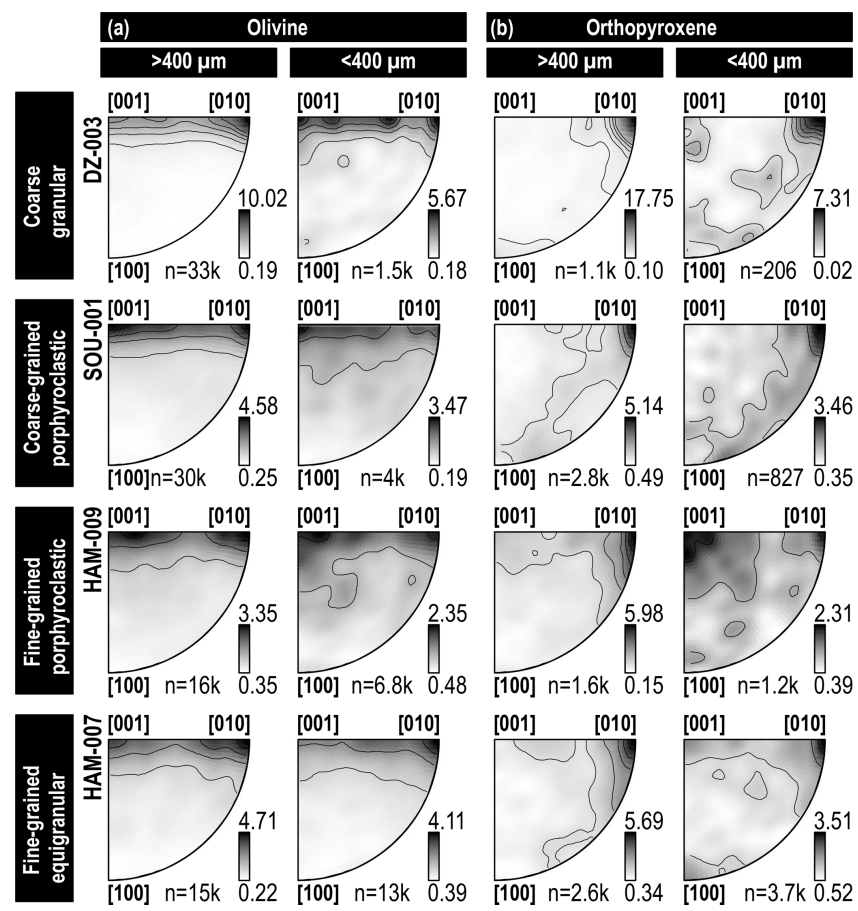

Figure 6. Rotation axes accommodating low-angle $\left(2-12^{\circ}\right)$ misorientations in the large ( $>400 \mu \mathrm{m}$ equivalent diameter) and small ( $<400 \mu \mathrm{m}$ equivalent diameter) grain fraction of olivine (a) and orthopyroxene (b). Data are represented in inverse pole figures with contouring at 0.5 multiples of uniform distribution. $N$ denotes the number of pixels plotted.

perature than the corresponding cores using the $T_{\mathrm{Cr}-\mathrm{Al}-\mathrm{Opx}}$ method, whereas they record similar or slightly higher temperatures than the cores by the two-pyroxene geothermometer (Fig. 7b). We observe a weak match of the two geothermometric methods only in a few coarse-grained rocks, typically in the range of approximately $920-1050^{\circ} \mathrm{C}$, which potentially reflects chemical disequilibrium between the pyroxenes. Nevertheless, the calculated temperatures are the lowest in the fine-grained rocks regardless of the calculation method.

\section{Discussion}

\subsection{The role of strain localization and melt infiltration}

The Oran mantle xenoliths show a variable grain size ranging from coarse granular to fine-grained equigranular textures uncorrelated with modal variations (Fig. 2a-b). In polymineralic mantle rocks, second phases such as pyroxenes or spinel are well known to keep steady-state grain size of dynamically recrystallized olivine small by pinning or dragging the grain boundaries of the matrix phase (e.g., Warren and Hirth, 2006; Precigout et al., 2007; Skemer et al., 2010; Linckens et al., 2011b). In fact, the olivine grain size in the Oran peridotites shows systematic correlations with the ratio between pyroxene grain size and volume fraction (i.e., Zener parameter; see Herwegh et al., 2011 for a review) (Fig. 8a-b). Since the fraction of secondary phases other than pyroxenes is very low $(<1 \%$; Table 1$)$ in the studied xenoliths, we include only olivine and pyroxenes in our analysis, but we plot ortho- and clinopyroxene separately to distinguish potential differences in their effect on olivine grain size. Dynamic recrystallization - which is a common grain size reduction process in dislocation accommodated creep (e.g., De Bresser et al., 2001) - is apparent in the microstructure of the coarse-grained xenoliths if orthopyroxene is considered as a second-phase particle (Fig. 8a). In contrast, in the case of clinopyroxene being a secondphase particle, the coarse-grained peridotites plot along the transition between dynamic recrystallization-controlled and second-phase-controlled fields (Fig. 8b). These observations suggest that in the coarse-grained peridotites olivine yielded a relatively stable grain size by dynamic recrystallization, which was moderately influenced by the presence of clinopyroxene and it was not pinned by orthopyroxene. In the finegrained microstructures, olivine grain size strongly depends on the Zener parameter (Fig. 8a-b), implying that small interstitial ortho- and clinopyroxenes dispersed in the fabric impeded olivine grain growth through pinning. These data are consistent with those in previous studies where olivine grain size was interpreted as controlled by pyroxenes through pinning during ductile deformation and strain localization processes (e.g., Warren and Hirth, 2006; Herwegh et al., 2011; Linckens et al., 2011a, b; Tasaka and Hiraga, 2013; Tasaka et al., 2014; Hansen and Warren, 2015).

Grain size reduction in mantle xenoliths is symptomatic of increasing strain localization in relatively cold, stiff and high-stress domains of the mantle lithosphere (e.g., Drury et al., 1991; Karato, 2008; Linckens et al., 2011b; Vauchez et al., 2012; Tommasi and Vauchez, 2015). Strain localization in peridotites is often linked to mantle metasomatism because fine-grained microstructures frequently display relative enrichment of incompatible trace elements (e.g., Yang et al., 2010) or evidence of modal metasomatism (e.g., Newman et al., 1999; Dijkstra et al., 2002). The relative timing between strain localization and metasomatism is however not always evident. Detailed studies of the textures and CPO of olivine and pyroxenes help to unravel if the texture is consistent with solid-state or melt-present deformation (Tommasi et al., 2008; Higgie and Tommasi, 2014) that are of interest to decipher the origin and significance of grain size variations in the Oran xenolith suite.

\subsubsection{Coarse-grained peridotites}

In Oran coarse-grained peridotites, olivine and orthopyroxene show CPO coherent with coeval deformation by dislocation creep at high temperature. The alignment of $[100]_{\mathrm{O} 1}$ and $[001]_{\text {opx }}$ crystallographic axes (Fig. 5a) subparallel to 


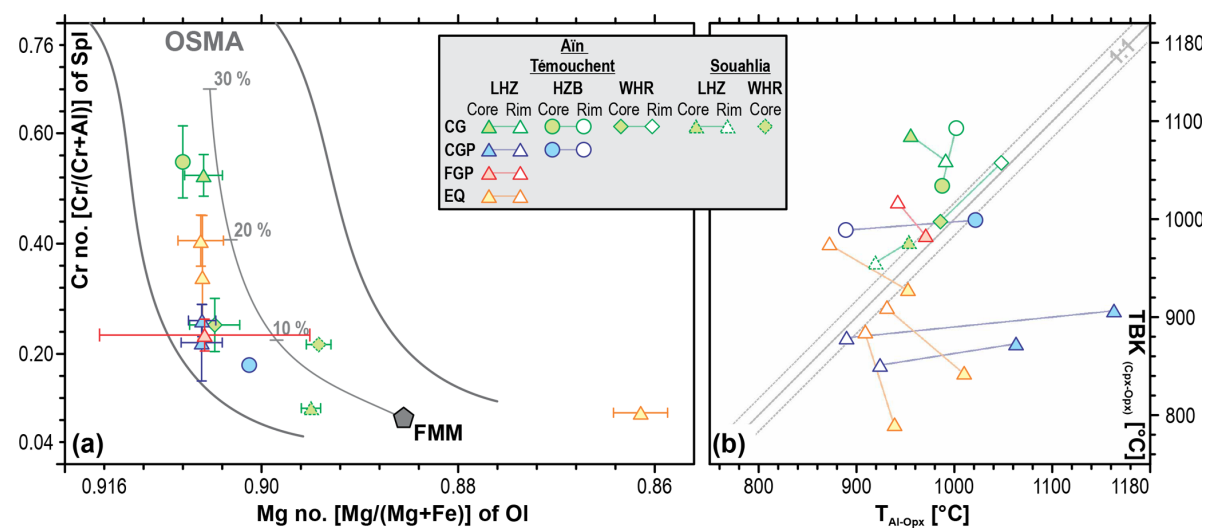

Figure 7. (a) Plot of spinel $\mathrm{Cr}$ no. $[\mathrm{Cr} /(\mathrm{Cr}+\mathrm{Al})]$ versus olivine $\mathrm{Mg}$ no. $[\mathrm{Mg} /(\mathrm{Mg}+\mathrm{Fe})]$ expressed as atom per formula units. The olivinespinel mantle array (OSMA) and degrees of partial melting are from Arai (1994). FMM (grey pentagon) is the fertile MORB mantle (after Pearce et al., 2000). Ol: olivine; Spl: spinel. (b) Estimated temperatures of Oran mantle peridotites based on the Cr-Al-orthopyroxene $\left(T_{\mathrm{Al}-\mathrm{Opx}}\right)$ geothermometer of Witt-Eickschen and Seck (1991), and the two-pyroxene solvus $\left(T_{\mathrm{Cpx}}-\mathrm{Opx}\right)$ geothermometer of Brey and Köhler (1990). Data are presented in Table 1; see abbreviations in Fig. 2.

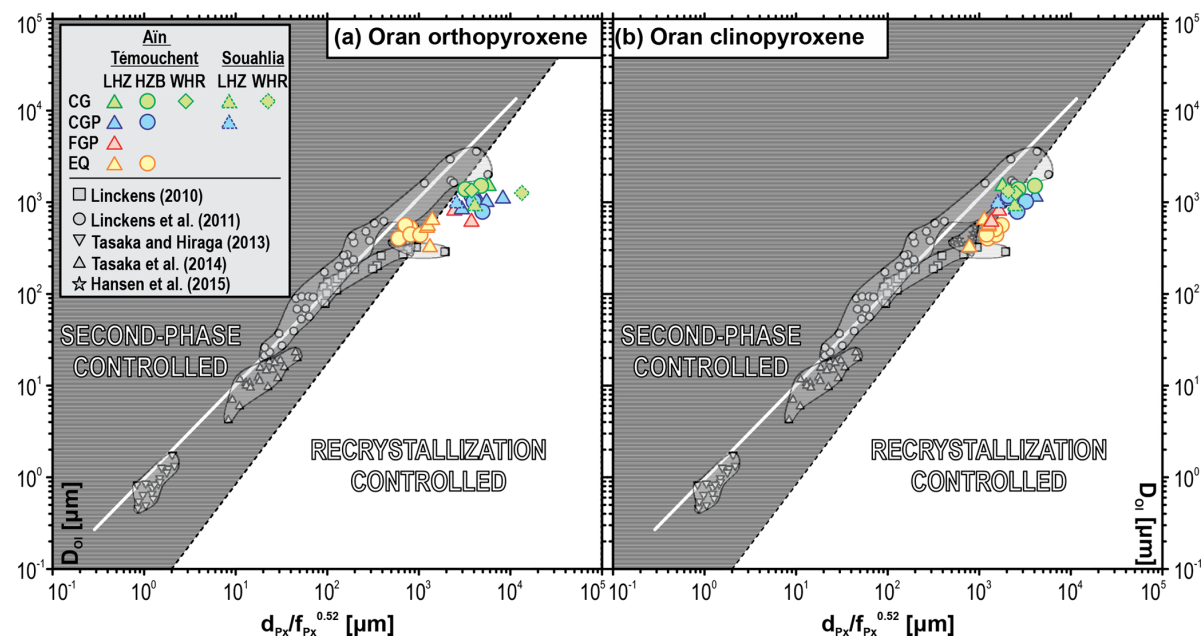

Figure 8. (a) Zener diagram showing average area-weighted olivine grain size $\left(D_{\mathrm{Ol}}\right)$ as a function of grain size and volume fraction of pyroxene $\left(d_{\mathrm{Px}} / f_{\mathrm{Px}}^{0.52}\right)$ in the Oran mantle xenoliths. Data are plotted considering orthopyroxene (a) and clinopyroxene (b) as secondary phases in the olivine matrix. The diagram shows the transition from second-phase (grey-shaded field) to dynamic recrystallization (whiteshaded field) controlled microstructures after Herwegh et al. (2011). Comparative data are from natural peridotite shear zones in the Oman ophiolite (Linckens, 2010; Linckens et al., 2011a, b; Tasaka et al., 2014) and the Josephine peridotite (Hansen et al., 2015), as well as deformation experiments on olivine-pyroxene aggregates (Tasaka and Hiraga, 2013). For plotting the data, a Zener parameter of $Z=0.52$ is used following Tasaka et al. (2014), and the solid white line in the background is the fit presented in their work. Abbreviations in the legend are the same as for Fig. 2.

the stretching lineation is consistent with dominant activation of (0kl)[100] slip systems in olivine and the (100)[001] slip system in orthopyroxene. Rotation axes accommodating low-angle $\left(2-12^{\circ}\right)$ misorientations of $\langle 0 \mathrm{vw}\rangle$ orientations in olivine and around [010] in orthopyroxene (Fig. 6) corroborate the activation of these slip systems (de Kloe, 2001). These slip systems are dominant in crystal-plastic deformation under low-stress, high-temperature $\left(>1000^{\circ} \mathrm{C}\right)$, lowpressure and fluid-absent conditions attributed to constrictional strain (see Carter and Avé Lallemant, 1970; Durham and Goetze, 1977; Mainprice et al., 2005; Karato, 2008; Jung et al., 2010; Demouchy et al., 2014; Chatzaras et al., 2016; Tommasi et al., 1999). The fine-grained pyroxenes in the matrix are strain-free and elongated (Fig. $3 \mathrm{c}$ and closeup view), and they occur in interstitial textural position at olivine-olivine grain boundaries (Fig. 3b). These features are inconsistent with neoblasts produced during dynamic recrystallization of porphyroclasts (Urai et al., 1986). Similar fine-grained pyroxenes in coarse-grained peridotites are interpreted as the result of post-kinematic crystallization of 
secondary pyroxene from the small melt fraction (Tommasi et al., 2008; Morales and Tommasi, 2011). The similar CPO and rotation axes of small and large orthopyroxene grains in Oran coarse-grained xenoliths (Fig. 5-6) indicate that interstitial orthopyroxenes deformed coherently with olivine and orthopyroxene porphyroclasts by dislocation creep. This observation excludes a post-kinematic crystallization origin for the fine-grained matrix pyroxenes. Their textural position (Fig. 3b) is consistent with crystallization after the small fraction of interstitial melts between olivine-olivine boundaries. The texture and $\mathrm{CPO}$ of fine-grained pyroxenes can better be accounted for if, upon crystallization from small melt fractions along olivine grain boundaries, they deformed by dislocation creep, followed by a last post-kinematic recovery stage. The Oran coarse-grained texture is then consistent with high- $T$ deformation at near-solidus conditions and infiltration of small melt fractions. Experimental studies of Holtzman et al. (2003) show that small melt fractions in the presence of second-phase particles do not result in a switch of olivine CPO up to $6 \%$ melt fraction, which is consistent with low melt fractions inferred for the formation of fine-grained pyroxenes in the coarse-grained rocks.

\subsubsection{Fine-grained peridotites}

Relative to other textural types, the equigranular peridotites display a shift of olivine CPO symmetry towards [010] fiber and have a lower fabric strength, and the orthopyroxene CPOs are inconsistent with coeval deformation by dislocation creep (Figs. 4-5; Table 1). The fine grain size of olivine and pyroxenes is consistent with high-stress deformation likely in mantle shear zones. Several processes may result in [010]-fiber CPOs in olivine: axial compression or 3-D transpressive deformation controlled by the finite strain geometry (Nicolas et al., 1973; Tommasi et al., 1999; Chatzaras et al., 2016); static recrystallization (Tommasi et al., 2008); activation of [100] and [001] glide directions at high pressure or stress (Tommasi et al., 2000; Mainprice et al., 2005); and melt-present deformation (Holtzman et al., 2003; Le Roux et al., 2008; Higgie and Tommasi, 2012). The preponderance of [010]-fiber-like CPO in olivines of equigranular peridotite xenoliths and their fine grain size may be compatible with deformation in transpression in mantle shear zones. Transpressional deformation alone, however, hardly explains the increasing dispersion and weakening of the olivine $\mathrm{CPO}$ with increasing pyroxene content. The development of [010]-fiber $\mathrm{CPO}$ during annealing requires selective grain growth that results in tabular crystal morphologies flattened parallel to the (010) plane (Tommasi et al., 2008). This model is at odds with the overall fine grain size and polygonal olivine crystal shapes in the equigranular textures (Fig. 3d-f). The spinel- to plagioclase-facies origin of the Oran xenoliths indicates that deformation took place at shallow depth, where the prevailing pressure conditions were too low for the activation of [001] glide (Mainprice et al., 2005; Vauchez et al., 2005). In small olivine grains, intracrystalline misorientations are accommodated mainly by rotations around [010] (Fig. 6a). This rotation axis is compatible with the activation of either (001)[100] or (100)[001] slip at tilt subgrain boundaries (e.g., de Kloe, 2001). The former slip system has been reported in solid-state deformation experiments at moderate water content (12-60 wt ppm $\left.\mathrm{H}_{2} \mathrm{O}\right)$, moderate stress (400 MPa) and pressure (2 GPa) (Katayama et al., 2004), but it does not disperse $[100]_{\mathrm{Ol}}$ crystallographic axes. The latter slip may reflect high-stress deformation and can contribute to the development of [010]-fiber olivine CPO symmetry. In the lack of further microstructural evidence, we cannot differentiate between these two possibilities, but considering the higher concentration of [100 $]_{\mathrm{Ol}}$ axes with respect to $[001]_{\mathrm{Ol}}$ in every sample, we suspect that dominant activation of [001] glide is less likely. Thus, we favor the latter hypothesis that is shear deformation of olivine in the presence of melt to explain the shift towards [010]-fiber olivine patterns in the equigranular peridotites. Alternatively, the transition of olivine CPO symmetry toward axial [010] in the fine-grained xenoliths may have developed enhanced by several of the above factors, of which the most likely scenario would be focused melt migration in a transpressional mantle shear zone, considering the geodynamic environment of the Oran volcanic field. Nevertheless, in the observed textures, the crystallographic axes of small orthopyroxenes are weakly oriented and, occasionally, distributed subparallel to those of olivine (Figs. 5b and S1). Similar correlation between olivine and orthopyroxene CPOs in orthopyroxeneimpregnated dunites from the Bay of Islands ophiolite (Suhr, 1993), in ultramylonitic shear zones from the Othris ophiolite (Dijkstra et al., 2002) and in fluid-assisted ductile strain localization from the Ronda massif (Hidas et al., 2016b), has been interpreted as having formed due to synkinematic melt/fluid-facilitated dissolution-precipitation processes. In the Oran equigranular peridotites, we interpret the CPO of interstitial small orthopyroxenes similarly, and we propose that they record constrained synkinematic crystallization from a melt phase. As in coarse-grained peridotites, the lack of intracrystalline deformation in equigranular peridotites points to a post-kinematic recovery stage, possibly enhanced by the presence of melts as proposed by Rampone et al. (2010) and Hidas et al. (2016a) in mantle xenoliths from Tallante.

The microstructure and CPO of fine-grained porphyroclastic peridotites are transitional between the coarse-grained and the equigranular peridotites (Figs. 2, 4). The orthopyroxene porphyroclasts have a coherent CPO with large olivines, which can be interpreted by the same operative slip systems as those discussed earlier in the coarse-grained rocks. In the fine-grained matrix, olivine $\mathrm{CPO}$ is identical to that of larger olivine grains but orthopyroxene CPO is not coherent with a coeval solid-state deformation. This duality is corroborated by the analysis of intracrystalline rotation axes that show $\langle 0 \mathrm{vw}\rangle$ orientations in large olivines and a predominant maximum around [010] axis in orthopyroxene porphy- 
roclasts, similarly to the coarse-grained peridotites, and the occurrence of $[010]_{\mathrm{Ol}}$ and $[001]_{\mathrm{Opx}}$ axes in the small grains, similarly to the equigranular ones (Fig. 6). These observations attest for the increasing impact of melts on the deformation from coarse-grained to fine-grained microstructures.

Deformation in the presence of melt may result in weak olivine CPO due to partitioning of the deformation between dislocation creep and diffusion-assisted grain boundary sliding (Holtzman et al., 2003; Zimmerman and Kohlstedt, 2004; Le Roux et al., 2008). This is consistent with our microstructural observations because olivine CPO is the weakest in the equigranular peridotites that record the shift of olivine CPO symmetry towards [010] fiber (Fig. 4). The presence of melts is further corroborated by the highest abundance of fine-grained pyroxenes in the equigranular peridotites (Table 1).

The presence of melt-related small pyroxenes in the coarse-grained rocks showing coherent CPO with olivine, the deformation mechanisms that are consistent with the presence of melts in the equigranular samples, and the transitional microstructural features of fine-grained porphyroclastic peridotites suggest synkinematic focusing of melts in the fine-grained peridotites. Such positive feedback between melt/fluid migration and strain localization is often observed in narrow ductile mantle shear zones (Downes, 1990; Kelemen and Dick, 1995; Dijkstra et al., 2002; Yang et al., 2010; Kruckenberg et al., 2013; Hidas et al., 2016b). Finally, based on the microstructural evidence for orthopyroxene replacement by clinopyroxene and the dominantly identical CPO of both pyroxenes in each xenolith, we suggest that crystallographic control by the orthopyroxene crystal structure during the crystallization of clinopyroxene resulted in a clinopyroxene $\mathrm{CPO}$ that follows that of orthopyroxene.

\subsection{Record of reactive melt transport in the Oran shallow SCLM}

The Oran mantle xenoliths originate from the spinel- to plagioclase-facies SCLM, and the major element contents of their olivine and spinel indicate that they are residual peridotites produced by relatively high degrees of partial melting (10\%-25\%; Fig. 7a). However, apart from one harzburgite, the refractory composition ( $>10 \%$ of partial melting) is often coupled to lherzolite or wehrlite lithologies (Fig. 7a). This observation suggests that the formation of clinopyroxene-rich modal composition by melt-rock reaction proceeded in a variously depleted refractory - likely harzburgite - protolith. Modal variations (Fig. 2a) and textural evidence (Fig. 3b) in most peridotites are consistent with the hypothesis that clinopyroxene crystallization was accompanied by dissolution of orthopyroxene and possibly minor precipitation of olivine. Based on the modal content (Table 1) and the major element geochemistry of the mineral cores (Table S1), we estimated the whole-rock major element composition of the studied rocks (Table 2). Figure 9 shows the

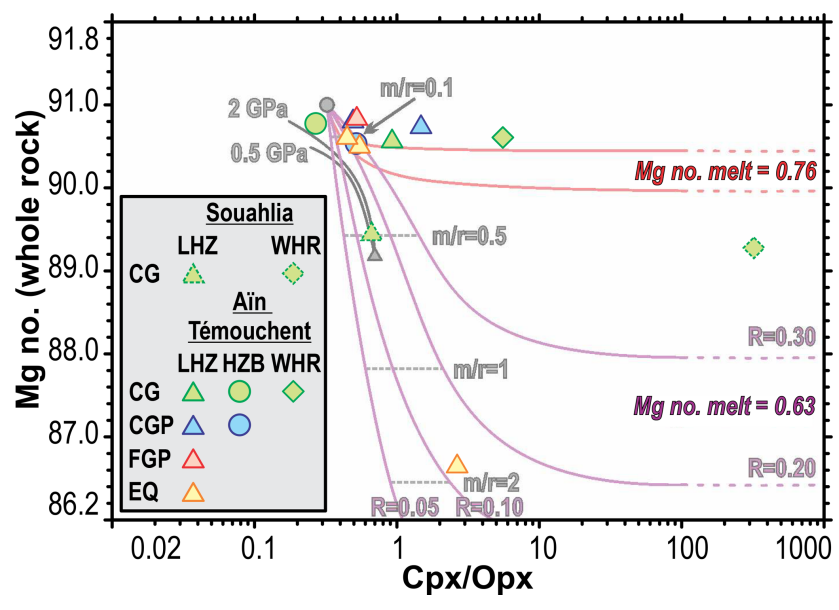

Figure 9. Clinopyroxene / orthopyroxene (Cpx / Opx) ratio of representative Oran mantle peridotites in the function of their calculated whole-rock $\mathrm{Mg}$ no. Data are compared to the results of modeling of batch partial melting (grey solid lines) in the range of 0.52.0 GPa (Varas-Reus et al., 2016, and references therein) and the variations produced by interaction of a refractory peridotite $\mathrm{Mg}$ no. is 0.91 ; $\mathrm{Cpx} / \mathrm{Opx}$ is 0.32 ) with percolating high-Mg no. (0.76; red solid lines) and low-Mg no. (0.63; purple solid lines) basaltic liquid involving Cpx-forming reactions at decreasing melt mass (Ionov et al., 2005). For the low-Mg no. melt, $R$ values indicate the mass ratio of crystallized minerals to infiltrated melt ranging from 0.02 to 0.3 , and grey dashed lines denote the melt-rock $(\mathrm{m} / \mathrm{r})$ ratio. For the high-Mg no. melt composition, all modeling results plot between the red lines. Dashed lines indicate extrapolation from original numerical modeling presented in Ionov et al. (2005). See text for further details and Fig. 2 for abbreviations shown in the legend.

covariation of bulk rock $\mathrm{Mg}$ no. and $\mathrm{Cpx} / \mathrm{Opx}$ ratios. In this figure, we also illustrate the trend of batch partial melting of a fertile lherzolite at $0.5-2.0 \mathrm{GPa}$ (adapted from Varas-Reus et al., 2016, and references therein) together with the predicted curves from numerical modeling involving precipitation of clinopyroxene \pm olivine at the expense of orthopyroxene in the spinel stability field (adapted from the model of Ionov et al., 2005). Ionov et al. (2005) modeled the interaction of refractory harzburgite ( $\mathrm{Mg}$ no. is 91.0 ; $\mathrm{Cpx} / \mathrm{Opx}$ is 0.32 ) with percolating basaltic liquids having either a primitive, high$\mathrm{Mg}$ no. (0.76) or an evolved, low-Mg no. (0.63) composition, involving clinopyroxene-forming reactions at decreasing melt mass.

Apart from a few coarse-grained peridotites, batch melting in the spinel facies is inconsistent with the composition of most Oran xenoliths. To explain the composition of these rocks by batch melting processes, significantly higher pressures are required (>3 GPa; e.g., Varas-Reus et al., 2016, and references therein), which is not compatible with the shallow SCLM origin of the samples. In contrast, the modal variations and the compositional variability of the studied xenoliths can be plausibly explained by wehrlitization. Unlike the expected high $\mathrm{Na}_{2} \mathrm{O} / \mathrm{Al}_{2} \mathrm{O}_{3}$ values accompanied with the 
Table 2. Calculated whole-rock major element composition of the Oran mantle xenoliths. $\mathrm{FeO} *$ all iron as $\mathrm{Fe}^{2+} ; \mathrm{Mg}$ no. is $\mathrm{Mg} /(\mathrm{Mg}+\mathrm{Fe})$ in $\mathrm{mol} \%$.

\begin{tabular}{|c|c|c|c|c|c|c|c|c|c|c|c|c|}
\hline & DZ-002 & DZ-003 & DZ-007 & DZ-009 & GU-001 & HAM-001 & HAM-005b & HAM-012 & HAM-017 & HAM-018 & SOU-002 & SOU-003 \\
\hline $\mathrm{SiO}_{2}$ & 43.9 & 41.6 & 42.3 & 43.7 & 42.3 & 43.9 & 43.2 & 41.2 & 43.2 & 44.4 & 44.3 & 34.8 \\
\hline $\mathrm{TiO}_{2}$ & 0.02 & 0.04 & 0.01 & 0.11 & 0.07 & 0.06 & 0.02 & 0.06 & 0.08 & 0.11 & 0.17 & 0.03 \\
\hline $\mathrm{Al}_{2} \mathrm{O}_{3}$ & 0.92 & 0.57 & 0.72 & 2.17 & 1.79 & 1.23 & 1.06 & 0.95 & 0.96 & 2.16 & 4.42 & 0.40 \\
\hline $\mathrm{Cr}_{2} \mathrm{O}_{3}$ & 0.48 & 0.36 & 0.18 & 0.44 & 0.57 & 0.31 & 0.30 & 0.26 & 0.41 & 0.27 & 0.60 & 0.18 \\
\hline $\mathrm{FeO} *$ & 7.88 & 8.70 & 8.52 & 7.47 & 8.10 & 8.24 & 8.03 & 8.52 & 8.08 & 10.3 & 7.74 & 9.57 \\
\hline $\mathrm{MnO}$ & 0.14 & 0.12 & 0.14 & 0.18 & 0.15 & 0.15 & 0.15 & 0.12 & 0.11 & 0.23 & 0.14 & 0.22 \\
\hline $\mathrm{NiO}$ & 0.30 & 0.35 & 0.34 & 0.32 & 0.30 & 0.28 & 0.34 & 0.34 & 0.28 & 0.20 & 0.24 & 0.32 \\
\hline $\mathrm{MgO}$ & 43.5 & 46.9 & 45.7 & 41.4 & 44.5 & 44.6 & 44.7 & 45.6 & 43.7 & 37.4 & 36.8 & 44.7 \\
\hline $\mathrm{CaO}$ & 3.85 & 1.79 & 1.86 & 4.30 & 2.21 & 1.21 & 2.77 & 2.36 & 3.10 & 2.96 & 5.45 & 0.08 \\
\hline $\mathrm{Na}_{2} \mathrm{O}$ & 0.16 & 0.07 & 0.11 & 0.32 & 0.15 & 0.06 & 0.14 & 0.11 & 0.17 & 0.14 & 0.47 & 0.00 \\
\hline $\mathrm{K}_{2} \mathrm{O}$ & 0.01 & 0.00 & 0.01 & 0.00 & 0.00 & 0.00 & 0.01 & 0.00 & 0.01 & 0.00 & 0.00 & 0.00 \\
\hline Total & 101.2 & 100.5 & 99.9 & 100.4 & 100.2 & 100.0 & 100.7 & 99.5 & 100.1 & 98.1 & 100.3 & 90.3 \\
\hline Mg no. & 0.908 & 0.906 & 0.905 & 0.908 & 0.907 & 0.906 & 0.908 & 0.905 & 0.906 & 0.867 & 0.895 & 0.893 \\
\hline
\end{tabular}

presence of apatite and jadeitic clinopyroxene in wehrlites related to carbonatites $\left(\mathrm{Na}_{2} \mathrm{O} / \mathrm{Al}_{2} \mathrm{O}_{3}\right.$ in the whole rock: 0.44 0.49, $\mathrm{Na}_{2} \mathrm{O}$ in Cpx: $1.5 \mathrm{wt} \%-2.5 \mathrm{wt} \%$; Yaxley et al., 1991; Raffone et al., 2009), the Oran xenoliths have petrographic and geochemical signatures $\left(\mathrm{Na}_{2} \mathrm{O} / \mathrm{Al}_{2} \mathrm{O}_{3}\right.$ in the whole rock: $<0.02-0.17 ; \mathrm{Na}_{2} \mathrm{O}$ in Cpx: 0.92 wt \%-1.59 wt \%; Tables 2 and S1) typical of mantle wall rocks that interacted with melts relatively close to magma conduits or porous flow channels (Bodinier et al., 1990; Ionov et al., 2005). The composition of most coarse-grained mantle peridotites is consistent with interaction with a high-Mg no. liquid at increasing melt-rock ratios from lherzolite towards wehrlite (Fig. 9). Similarly, the composition of fine-grained lherzolites can be explained by interaction with a low-Mg no. melt at low melt-rock ratio (Fig. 9). Comparison with numerical modeling suggests that the low Mg no. of a fine-grained lherzolite (sample HAM-018) may reflect interaction with a low$\mathrm{Mg}$ no. melt at high melt-rock ratio. The composition of the coarse-grained wehrlite from Souahlia plots in between the results of the two numerical modeling provided in Ionov et al. (2005) (Fig. 9). This suggests either an interaction with a liquid having an intermediate $\mathrm{Mg}$ no. between the modeled cases, or interaction with a low-Mg no. melt at an increased mass ratio of crystallized minerals to infiltrated melt ( $R$ value $>0.3$ ). Even after considering the uncertainties in the orthopyroxene content in this sample - that may influence the Cpx / Opx ratios - in both cases, high melt-rock ratios are required to explain the whole-rock composition of this wehrlite sample.

In summary, except for the wehrlites, the composition of coarse-grained Oran mantle peridotites suggests interaction with a high-Mg no. melt at low melt-rock ratios, which is also supported by microstructural interpretation based on which deformation was accommodated under low-melt conditions in these textures. The formation of coarse-grained wehrlites requires an increase in the melt-rock ratio and an interaction with either a high- $\mathrm{Mg}$ no. or an intermediate- $\mathrm{Mg}$ no. melt. In contrast, the geochemical composition of many fine-grained Oran xenoliths, mostly lherzolites, is consistent with interaction with low-Mg no. melts. These observations point to a change in the melt composition during melt-rock interaction. Primitive melts can evolve towards lower Mg no. upon crystallization and cooling (e.g., Pichavant and Macdonald, 2007, and references therein); thus, the composition of the coarse-grained Oran peridotites suggests interaction with a less fractionated melt at depth, likely at higher temperatures, while the composition of the equigranular peridotites can be addressed by interaction with a highly fractionated, evolved liquid of the primitive melt at shallower depths at increasing melt-rock ratios. This interpretation is supported by the slightly lower calculated temperature of the equigranular xenoliths compared to the coarse-grained ones (Fig. 7b).

\subsection{Role of the STEP fault in melt-rock interaction in the shallow SCLM}

In the Cenozoic geodynamic evolution of the western Mediterranean, thinning of the SCLM and crust, as well as opening of a slab window beneath the north African margin occurred during the late Miocene rapid westward retreat of the subduction system along the Tell-Rif STEP fault (e.g., Duggen et al., 2005; Chertova et al., 2014a, b, and references therein) (Fig. 10). The slab rollback and continental edge delamination resulted in a strong subduction suction causing the Canary plume material to flow $\geq 1500 \mathrm{~km}$ to the northeast (Duggen et al., 2009). This lateral mantle flow is supported by the seismic anisotropy signal beneath NW Africa that suggests E-W- to NE-SW-directed mantle flow (Diaz et al., 2010), as well as by the geochronological data and geochemical imprint of the Si-poor intraplate magmatism that shows northeastward-younging ages in NW Algeria (from approximately 7 to $0.8 \mathrm{Ma}$; Duggen et al., 2005). The position of the Oran volcanic field in the western Mediterranean suggests that its SCLM records processes related to mantle upwelling, lateral mantle flow, lithospheric tearing and for- 


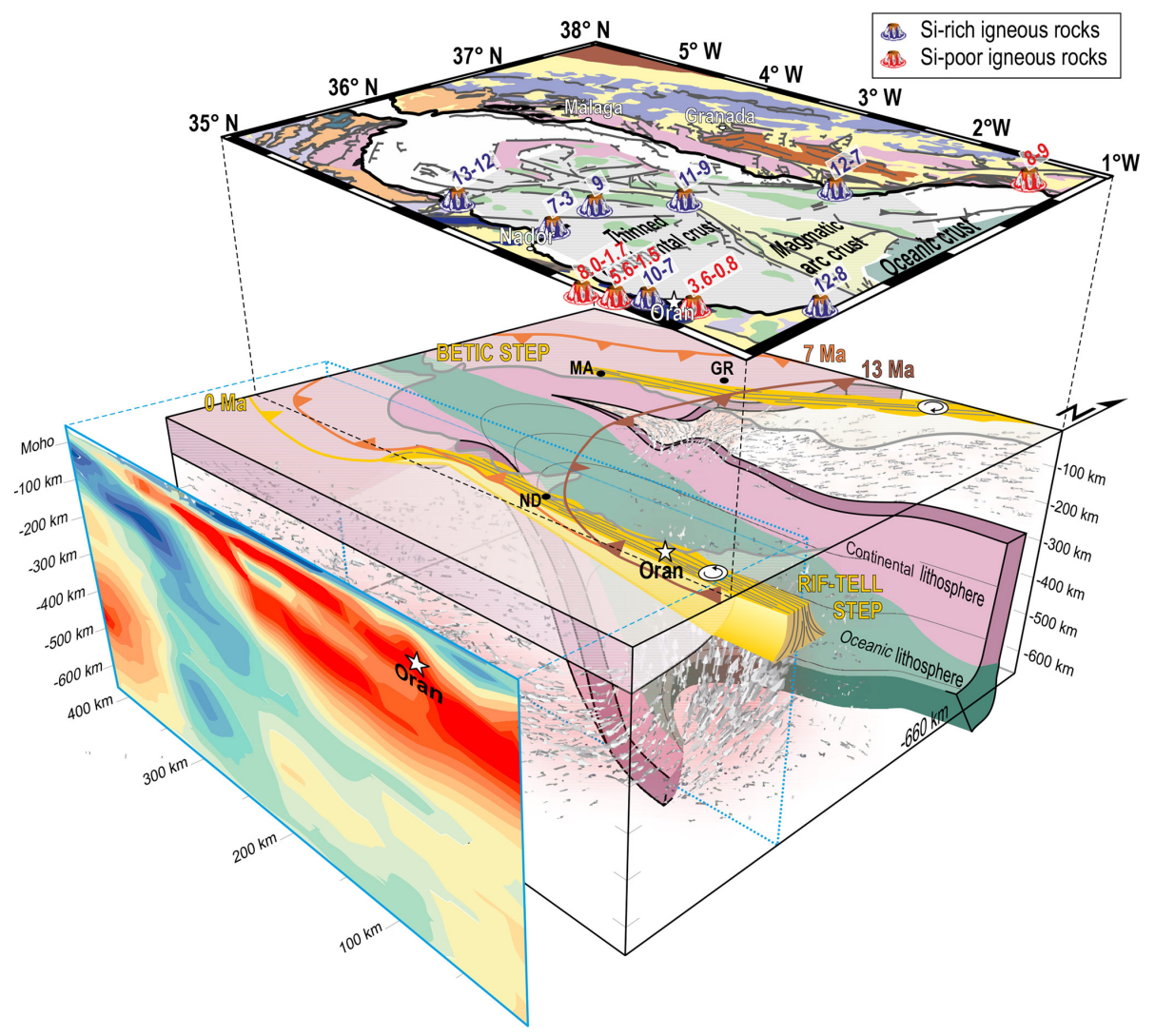

Figure 10. (a) Conceptual 3-D model of the western Mediterranean lithosphere, stripped from the overlying crust (modified after Mancilla et al., 2015). The original sketch showed the geometry of the lithosphere and its relation to the subducted oceanic slab as observed by tomographic studies (Spakman and Wortel, 2004; García-Castellanos and Villaseñor, 2011; Bezada et al., 2013). MA: Málaga; GR: Granada; ND: Nador. The superposed schematic geological map is presented in Fig. 1a. Types and ages of volcanism are compiled after Maury et al. (2000), Duggen et al. (2005) and Booth-Rea et al. (2007). On the left, seismic tomography is shown for an E-W cross section close to the Oran volcanic field (light blue dashed line in the 3-D sketch) after van Hinsbergen et al. (2014). Brown, orange and yellow solid lines indicate the estimated position of the subduction front at 13, 7 and 0 Ma, respectively (Booth-Rea et al., 2007 and Guillermo Booth-Rea, personal communication, 2018). The Betic and Tell-Rif STEP faults are constrained after Hidas et al. (2016a), Mancilla et al. (2018) and Chertova et al. (2014a, b). Mantle flow in the Iberian and north African slab windows is inspired by the work of Menant et al. (2016). The white star shows the provenance of Oran mantle xenoliths.

mation of STEP fault associated with the westward slab rollback of the subduction front (Fig. 10).

Upwelling of hot mantle material coupled to extension potentially eroded the base of the SCLM and resulted in the formation of large amounts of $\mathrm{SiO}_{2}$-undersaturated, high$\mathrm{Mg}$ no. alkaline melts at the north African margin (Duggen et al., 2005, 2009; Varas-Reus et al., 2017). During influx of such melts in refractory peridotites at mantle conditions $\left(>1000^{\circ} \mathrm{C}\right.$ and $1.0 \mathrm{GPa}$ ), the first reaction to take place is the dissolution of orthopyroxene and simultaneous crystallization of clinopyroxene and olivine (Shaw, 1999; Shaw et al., 2005; Lambart et al., 2012; Marchesi et al., 2017). Close to melt percolation channels, the interaction between the high-Mg no. melts and the harzburgite protolith proceeds until the complete exhaustion of orthopyroxene in the rocks, forming coarse-grained wehrlites (e.g., SOU-003 wehrlite; Fig. S1) that record high melt-rock ratios in the Oran xeno- liths (Fig. 9). The residual melt of the reaction has a higher alkaline, $\mathrm{SiO}_{2}, \mathrm{Al}_{2} \mathrm{O}_{3}$ - and $\mathrm{CaO}$-rich content with respect to the primitive high-Mg no. melt. Rapid $\mathrm{Fe}-\mathrm{Mg}$ exchange between mantle olivine and the melt (Gaetani and Watson, 2002; Shaw, 2004) might partially buffer the $\mathrm{MgO} / \mathrm{FeO}$ ratio in the residual melt and resulted in a decreasing $\mathrm{Mg}$ no. of olivine in mantle peridotites higher in the SCLM column. This stage is reflected in the low Mg no. $(<90.0)$ of some wehrlite and lherzolite xenoliths (Fig. 9). The evolution of the residual melt also leads the system towards saturation in orthopyroxene at shallower SCLM conditions. At the shallowest levels of the SCLM represented by the equigranular xenoliths, the highly evolved melts became saturated in orthopyroxene and the interaction resulted in the precipitation of small interstitial orthopyroxenes. Considering that small pyroxenes exert a strong influence on olivine grain size in the fine-grained mantle xenoliths (Fig. 8a-b), and the 
shift of olivine CPO towards [010]-fiber symmetry in some equigranular xenoliths suggests the presence of melts during deformation, we propose that this reaction stage was synkinematic. High time-integrated melt-rock ratios are plausibly accomplished by melt focusing (Phipps Morgan, 1987; Asimow and Stolper, 1999), which is compatible with synkinematic melt-rock interaction in a ductile shear zone. We therefore propose that coarse-grained xenoliths record deformation at moderate to high temperature by dislocation creep in a relatively dry or at least low-melt system, at the base of the studied SCLM column and farther from melt channels. This deformation may either be an older event preserved in the rocks or correspond to the lateral mantle flow from the $\mathrm{Ca}$ nary plume and mantle upwelling beneath the north African margin, resulting in axial-[100] olivine CPO symmetry that developed due to constrictional strain. As recorded in the porphyroclastic and particularly in the fine-grained equigranular xenoliths, at shallower levels of the SCLM, deformation was accommodated in the presence of increasing amounts of melts. This deformation is probably related to the westward propagation of the western Mediterranean subduction system along the Tell-Rif STEP fault parallel to the north African margin in the Miocene (Duggen et al., 2005; Chertova et al., 2014a, b), which resulted in the formation of ductile shear zones in the shallow SCLM (Fig. 10). These results suggest that wehrlitization of the Oran SCLM is a relatively young event, which took place in late Miocene to early Pleistocene times, and the observed variations in microstructures and olivine CPOs could reflect vertical and/or lateral heterogeneities along the north African margin.

\section{Conclusions}

The modal variation, microstructure and major element composition of mantle xenoliths from the Oran volcanic field (NW Algeria) are consistent with synkinematic melt-rock interaction in the shallow subcontinental lithospheric mantle. Coarse-grained mantle xenoliths record coherent olivine and orthopyroxene CPOs that developed at high temperature by dislocation creep in a dry or low-melt system. In the finegrained microstructures, olivine $\mathrm{CPO}$ records a shift towards [010]-fiber symmetry, indicating the presence of melts during deformation, and orthopyroxene CPO is not compatible with solid-state deformation. Clinopyroxene inherits the orientation of orthopyroxene during orthopyroxene-consuming and clinopyroxene-precipitating melt-rock reaction. The strong exert of small pyroxene crystals on the olivine grain size suggests their presence during deformation and points to channeling of reactive melts at the shallow subcontinental lithospheric mantle beneath the north African margin. The textural and geochemical records of the peridotites are consistent with the interaction of a refractory harzburgite protolith with a high-Mg no. melt at depth (resulting in the formation of coarse-grained clinopyroxene-rich lherzolite and wehrlite) and with a low-Mg no. evolved melt in the shallow subcontinental lithospheric mantle (forming fine-grained harzburgite). Based on the microstructural evidence, the melt-rock interaction was likely synkinematic. We propose that reactive melts formed during the operation of the Tell-Rif STEP fault beneath the north African margin during the Miocene westward retreat of the western Mediterranean subduction system.

Data availability. Geochemical data and calculated microstructural parameters are available in the paper and in the Supplement. The raw EBSD data files are available from the corresponding author upon request.

Supplement. The supplement related to this article is available online at: https://doi.org/10.5194/se-10-1099-2019-supplement.

Author contributions. $\mathrm{KH}$, CJG and CM carried out microstructural and geochemical data acquisition. $\mathrm{KH}, \mathrm{CJG}, \mathrm{GBR}, \mathrm{CM}$ and JLB participated in developing the core ideas presented in the paper in agreement with other co-authors. JLB, JMD, ALH and AAS collected the mantle xenoliths and granted access to the samples. All authors contributed to the manuscript writing either by directly formulating text or giving feedback on figures or specific chapters.

Competing interests. The authors declare that they have no conflict of interest.

Acknowledgements. We acknowledge the help of Zoltán Konc in the EMPA and EBSD data acquisition. We are grateful to David Mainprice (Géosciences Montpellier, France) for providing scripts and help in MTEX, and to László Előd Aradi (Lithosphere Fluid Research Lab, Eötvös Loránd University of Budapest, Hungary) for contributing to an earlier version of the EBSD database. We appreciate the help of Yassamina Meddi (Université des Sciences et de la Technologie Houari Boumédiène, Algeria) in providing documentation and illustration for the overview of geological context and sampling. We thank Theodoros Ntaflos, Rachel E. Bernard and Vasileios Chatzaras for the constructive ideas in their reviews, and we appreciate the editorial work of Florian Fusseis. Károly Hidas acknowledges funding by Ministerio de Economía y Competitividad (MINECO) (FPDI-2013-16253) and the Agencia Estatal de Investigación (CGL2016-81085-R). Claudio Marchesi acknowledges funding by Ramón y Cajal Fellowship (RYC-2012-11314) by the MINECO.

Financial support. This research has been supported by the Agencia Estatal de Investigación (grant nos. CGL2016-75224-R, CGL2016-81085-R and CGL2015-67130-C2-1-R), the Junta de Andalucía research groups RNM-131 and RNM-148, and the International Lithosphere Program (grant no. CC4-MEDYNA). Fellowships, research and infrastructure grants leading to this research 
have been co-funded by the European Social Fund (ESF) and the European Regional Development Fund (ERFD) of the European Commission.

Review statement. This paper was edited by Florian Fusseis and reviewed by Theodoros Ntaflos, Rachel E. Bernard, and Vasileios Chatzaras.

\section{References}

Abbassene, F., Chazot, G., Bellon, H., Bruguier, O., Ouabadi, A., Maury, R. C., Déverchére, J., Bosch, D., and Monié, P.: A 17 Ma onset for the post-collisional K-rich calc-alkaline magmatism in the Maghrebides: Evidence from Bougaroun (northeastern Algeria) and geodynamic implications, Tectonophysics, 674, 114134, https://doi.org/10.1016/j.tecto.2016.02.013, 2016.

Arai, S.: Characterization of spinel peridotites by olivinespinel compositional relationships: Review and interpretation, Chem. Geol., 113, 191-204, https://doi.org/10.1016/00092541(94)90066-3, 1994.

Asimow, P. D. and Stolper, E. M.: Steady-state mantle-melt interactions in one dimension, I, Equilibrium transport and melt focusing, J. Petrol., 40, 475-494, 1999.

Azdimousa, A., Jabaloy-Sánchez, A., Münch, P., MartínezMartínez, J. M., Booth-Rea, G., Vázquez-Vílchez, M., Asebriy, L., Bourgois, J., and González-Lodeiro, F.: Structure and exhumation of the Cap des Trois Fourches basement rocks (Eastern Rif, Morocco), J. Afr. Earth Sci., 150, 657-672, https://doi.org/10.1016/j.jafrearsci.2018.09.018, 2019.

Bachmann, F., Hielscher, R., and Schaeben, H.: Texture analysis with MTEX - free and open source software toolbox, Sol. St. Phen., 160, 63-68, 2010.

Bendoukha, R., M'hamed, M., Cottin, J.-Y., and Tebeliouna, M.: Nouvelles données sur les caractères dynamiques et géochimiques du volcanisme alcalin Mio-Plio-Quaternaire de L'Oranie (Algérie Nord-Occidentale), Bulletin du Service Géologique de l'Algérie, 20, 263-296, 2009.

Bezada, M. J., Humphreys, E. D., Toomey, D. R., Harnafi, M., Dávila, J. M., and Gallart, J.: Evidence for slab rollback in westernmost Mediterranean from improved upper mantle imaging, Earth Planet. Sc. Lett., 368, 51-60, https://doi.org/10.1016/j.eps1.2013.02.024, 2013.

Bodinier, J. L., Vasseur, G., Vernieres, J., Dupuy, C., and Fabries, J.: Mechanisms of mantle metasomatism: Geochemical evidence from the Lherz orogenic peridotite, J. Petrol., 31, 597-628, https://doi.org/10.1093/petrology/31.3.597, 1990.

Bodinier, J. L. and Godard, M.: 3.4 - Orogenic, Ophiolitic, and Abyssal Peridotites, in: Treatise on Geochemistry (Second Edition), edited by: Turekian, H. D. H. K., Elsevier, Oxford, 103167, 2014.

Booth-Rea, G., Ranero, C. R., Martinez-Martinez, J. M., and Grevemeyer, I.: Crustal types and Tertiary tectonic evolution of the Alboran sea, western Mediterranean, Geochem. Geophy. Geosy., 8, Q10005 https://doi.org/10.1029/2007gc001639, 2007.

Booth-Rea, G., Jabaloy-Sanchez, A., Azdimousa, A., Asebriy, L., Vilchez, M. V., and Martínez-Martínez, J. M.: Upper-crustal extension during oblique collision: the Temsamane extensional detachment (eastern Rif, Morocco), Terra Nova, 24, 505-512, https://doi.org/10.1111/j.1365-3121.2012.01089.x, 2012.

Booth-Rea, G., Gaidi, S., Melki, F., Marzougui, W., Azañón, J. M., Zargouni, F., Galvé, J. P., and Pérez-Peña, J. V.: Late Miocene Extensional Collapse of Northern Tunisia, Tectonics, 37, 16261647, https://doi.org/10.1029/2017TC004846, 2018 a.

Booth-Rea, G., R. Ranero, C., and Grevemeyer, I.: The Alboran volcanic-arc modulated the Messinian faunal exchange and salinity crisis, Sci. Rep., 8, 13015, https://doi.org/10.1038/s41598018-31307-7, 2018b.

Borghini, G., Fumagalli, P., and Rampone, E.: The Stability of Plagioclase in the Upper Mantle: Subsolidus Experiments on Fertile and Depleted Lherzolite, J. Petrol., 51, 229-254, https://doi.org/10.1093/petrology/egp079, 2010.

Brey, G. P. and Köhler, T.: Geothermobarometry in four-phase lherzolites, II, New thermobarometers, and practical assessment of existing thermobarometers, J. Petrol., 31, 1353-1378, 1990.

Carter, N. and Avé Lallemant, H.: High temperature flow of dunite and peridotite, Bull. Geol. Soc. Am., 81, 2181-2202, 1970.

Chatzaras, V., Kruckenberg, S. C., Cohen, S. M., Medaris, L. G., Withers, A. C., and Bagley, B.: Axial-type olivine crystallographic preferred orientations: The effect of strain geometry on mantle texture, J. Geophys. Res.-Sol. Ea., 121, 4895-4922, https://doi.org/10.1002/2015JB012628, 2016.

Chazot, G., Abbassene, F., Maury, R. C., Déverchère, J., Bellon, H., Ouabadi, A., and Bosch, D.: An overview on the origin of post-collisional Miocene magmatism in the Kabylies (northern Algeria): Evidence for crustal stacking, delamination and slab detachment, J. Afr. Earth Sci., 125, 27-41, https://doi.org/10.1016/j.jafrearsci.2016.10.005, 2017.

Chertova, M. V., Spakman, W., Geenen, T., van den Berg, A. P., and van Hinsbergen, D. J. J.: Underpinning tectonic reconstructions of the western Mediterranean region with dynamic slab evolution from 3-D numerical modeling, J. Geophys. Res.-Sol. Ea., 119, 2014JB011150, https://doi.org/10.1002/2014JB011150, 2014a.

Chertova, M. V., Spakman, W., van den Berg, A. P., and van Hinsbergen, D. J. J.: Absolute plate motions and regional subduction evolution, Geochem. Geophy. Geosy., 15, 3780-3792, https://doi.org/10.1002/2014GC005494, 2014b.

Comas, M. C., Platt, J. P., Soto, J. I., and Watts, A. B.: The origin and tectonic history of the Alboran Basin: Insights from Leg 161 results, in: Proceedings of the Ocean Drilling Program, Scientific Results, edited by: Zahn, R., Comas, M. C., and Klaus, A., College Station, TX, 555-580, 1999.

Coulon, C., Megartsi, M. H., Fourcade, S., Maury, R. C., Bellon, H., Louni-Hacini, A., Cotten, J., Coutelle, A., and Hermitte, D.: Post-collisional transition from calc-alkaline to alkaline volcanism during the Neogene in Oranie (Algeria): magmatic expression of a slab breakoff, Lithos, 62, 87-110, https://doi.org/10.1016/S0024-4937(02)00109-3, 2002.

De Bresser, J. H. P., Ter Heege, J. H., and Spiers, C. J.: Grain size reduction by dynamic recrystallization: can it result in major rheological weakening?, Int. J. Earth Sci., 90, 28-45, 2001.

de Kloe, R.: Deformation mechanisms and melt nano-structures in experimentally deformed olivine-orthopyroxene rocks with low melt fractions - An electron microscopy study, $\mathrm{PhD}$, Universiteit Utrecht, 176 pp., 2001.

Demouchy, S., Mussi, A., Barou, F., Tommasi, A., and Cordier, P.: Viscoplasticity of polycrystalline olivine experimentally de- 
formed at high pressure and $900^{\circ} \mathrm{C}$, Tectonophysics, 623, 123135, https://doi.org/10.1016/j.tecto.2014.03.022, 2014.

Diaz, J., Gallart, J., Villaseñor, A., Mancilla, F., Pazos, A., Córdoba, D., Pulgar, J. A., Ibarra, P., and Harnafi, M.: Mantle dynamics beneath the Gibraltar Arc (western Mediterranean) from shearwave splitting measurements on a dense seismic array, Geophys. Res. Lett., 37, L18304, https://doi.org/10.1029/2010GL044201, 2010.

Dijkstra, A. H., Drury, M. R., Vissers, R. L. M., and Newman, J.: On the role of melt-rock reaction in mantle shear zone formation in the Othris Peridotite Massif (Greece), J. Struct. Geol., 24, 14311450, 2002.

Downes, H.: Shear zones in the upper mantle - Relation between geochemical enrichment and deformation in mantle peridotites, Geology, 18, 374-377, 1990.

Drury, M. R., Vissers, R. L. M., Wal, D. V. D., and Strating, E. H. H.: Shear localisation in upper mantle peridotites, Pure Appl. Geophys., 137, 439-460, https://doi.org/10.1007/BF00879044, 1991.

Duggen, S., Hoernle, K., van den Bogaard, P., Rupke, L., and Morgan, J. P.: Deep roots of the Messinian salinity crisis, Nature, 422, 602-606, 2003.

Duggen, S., Hoernle, K., van den Bogaard, P., and Harris, C.: Magmatic evolution of the Alboran region: The role of subduction in forming the western Mediterranean and causing the Messinian Salinity Crisis, Earth Planet. Sc. Lett., 218, 91-108, https://doi.org/10.1016/s0012-821x(03)00632-0, 2004.

Duggen, S., Hoernle, K., Van den Bogaard, P., and GarbeSchonberg, D.: Post-collisional transition from subductionto intraplate-type magmatism in the westernmost Mediterranean: Evidence for continental-edge delamination of subcontinental lithosphere, J. Petrol., 46, 1155-1201, https://doi.org/10.1093/petrology/egi013, 2005.

Duggen, S., Hoernle, K., Kluegel, A., Geldmacher, J., Thirlwall, M., Hauff, F., Lowry, D., and Oates, N.: Geochemical zonation of the Miocene Alborán Basin volcanism (westernmost Mediterranean): geodynamic implications, Contrib. Mineral. Petr., 156, 577-593, https://doi.org/10.1007/s00410-008-0302-4, 2008.

Duggen, S., Hoernle, K. A., Hauff, F., Klugel, A., Bouabdellah, M., and Thirlwall, M. F.: Flow of Canary mantle plume material through a subcontinental lithospheric corridor beneath Africa to the Mediterranean, Geology, 37, 283-286, https://doi.org/10.1130/g25426a.1, 2009.

Durham, W. B. and Goetze, C.: Plastic flow of oriented single crystals of olivine: 1. Mechanical data, J. Geophys. Res., 82, 5737 5753, https://doi.org/10.1029/JB082i036p05737, 1977.

Faccenna, C., Piromallo, C., Crespo-Blanc, A., Jolivet, L., and Rossetti, F.: Lateral slab deformation and the origin of the western Mediterranean arcs, Tectonics, 23, Tc1012 https://doi.org/10.1029/2002tc001488, 2004.

Faccenna, C., Becker, T. W., Auer, L., Billi, A., Boschi, L., Brun, J. P., Capitanio, F. A., Funiciello, F., Horvàth, F., Jolivet, L., Piromallo, C., Royden, L., Rossetti, F., and Serpelloni, E.: Mantle dynamics in the Mediterranean, Rev. Geophys., 52, 283-332, https://doi.org/10.1002/2013RG000444, 2014.

Gaetani, G. A. and Watson, E. B.: Modeling the major-element evolution of olivine-hosted melt inclusions, Chem. Geol., 183, 2541, 2002.
Garcia-Castellanos, D. and Villasenor, A.: Messinian salinity crisis regulated by competing tectonics and erosion at the Gibraltar arc, Nature, 480, 359-U108, https://doi.org/10.1038/nature10651, 2011.

Giaconia, F., Booth-Rea, G., Martínez-Martínez, J. M., Azañón, J. M., Storti, F., and Artoni, A.: Heterogeneous extension and the role of transfer faults in the development of the southeastern Betic basins (SE Spain), Tectonics, 33, 2467-2489, https://doi.org/10.1002/2014TC003681, 2014.

Gómez de la Peña, L., Ranero, C. R., and Gràcia, E.: The Crustal Domains of the Alboran Basin (Western Mediterranean), Tectonics, 37, 3352-3377, https://doi.org/10.1029/2017TC004946, 2018.

Govers, R. and Wortel, M. J. R.: Lithosphere tearing at STEP faults: Response to edges of subduction zones, Earth Planet. Sc. Lett., 236, 505-523, https://doi.org/10.1016/j.epsl.2005.03.022, 2005.

Gutscher, M. A., Malod, J., Rehault, J. P., Contrucci, I., Klingelhoefer, F., Mendes-Victor, L., and Spakman, W.: Evidence for active subduction beneath Gibraltar, Geology, 30, 1071-1074, https://doi.org/10.1130/00917613(2002)030<1071:efasbg>2.0.co;2, 2002.

Gutscher, M. A., Dominguez, S., Westbrook, G. K., Le Roy, P., Rosas, F., Duarte, J. C., Terrinha, P., Miranda, J. M., Graindorge, D., Gailler, A., Sallares, V., and Bartolome, R.: The Gibraltar subduction: A decade of new geophysical data, Tectonophysics, 574-575, 72-91, https://doi.org/10.1016/j.tecto.2012.08.038, 2012.

Hansen, L. N. and Warren, J. M.: Quantifying the effect of pyroxene on deformation of peridotite in a natural shear zone, J. Geophys. Res.-Sol. Ea., 120, 2014JB011584, https://doi.org/10.1002/2014JB011584, 2015.

Herwegh, M., Linckens, J., Ebert, A., Berger, A., and Brodhag, S. H.: The role of second phases for controlling microstructural evolution in polymineralic rocks: A review, J. Struct. Geol., 33 1728-1750, https://doi.org/10.1016/j.jsg.2011.08.011, 2011.

Hidas, K., Konc, Z., Garrido, C. J., Tommasi, A., Vauchez, A., Padrón-Navarta, J. A., Marchesi, C., Booth-Rea, G., Acosta-Vigil, A., Szabó, C., Varas-Reus, M. I., and Gervilla, F.: Flow in the western Mediterranean shallow mantle: Insights from xenoliths in Pliocene alkali basalts from SE Iberia (eastern Betics, Spain), Tectonics, 35, 2657-2676, https://doi.org/10.1002/2016TC004165, 2016a.

Hidas, K., Tommasi, A., Garrido, C. J., Padrón-Navarta, J. A., Mainprice, D., Vauchez, A., Barou, F., and Marchesi, C.: Fluid-assisted strain localization in the shallow subcontinental lithospheric mantle, Lithos, 262, 636-650, https://doi.org/10.1016/j.lithos.2016.07.038, 2016b.

Hielscher, R. and Schaeben, H.: A novel pole figure inversion method: specification of the MTEX algorithm, J. Appl. Crystallogr., 41, 1024-1037, https://doi.org/10.1107/S0021889808030112, 2008.

Higgie, K. and Tommasi, A.: Feedbacks between deformation and melt distribution in the crust-mantle transition zone of the Oman ophiolite, Earth Planet. Sc. Lett., 359, 61-72, https://doi.org/10.1016/j.epsl.2012.10.003, 2012.

Higgie, K. and Tommasi, A.: Deformation in a partially molten mantle: Constraints from plagioclase lherzolites from Lanzo, western Alps, Tectonophysics, 615, 167-181, https://doi.org/10.1016/j.tecto.2014.01.007, 2014. 
Hoernle, K., Van den Bogaard, P., Duggen, S., Mocek, B., and Garbe-Schonberg, D.: Evidence for Miocene subduction beneath the Alboran Sea: ${ }^{40} \mathrm{Ar} /{ }^{39} \mathrm{Ar}$ dating and geochemistry of volcanic rocks from holes 977A and 978A, in: Proceedings of the Ocean Drilling Program, Scientific Results, edited by: Zahn, R., Comas, M. C., and Klaus, A., Ocean Drilling Program, Texas A\&M University, USA, 357-373, 1999.

Holtzman, B. K., Kohlstedt, D. L., Zimmerman, M. E., Heidelbach, F., Hiraga, T., and Hustoft, J.: Melt segregation and strain partitioning: Implications for seismic anisotropy and mantle flow, Science, 301, 1227-1230, https://doi.org/10.1126/science.1087132, 2003.

Ionov, D., A., Chanefo, I., and Bodinier, J.-L.: Origin of Fe-rich lherzolites and wehrlites from Tok, SE Siberia by reactive melt percolation in refractory mantle peridotites, Contrib. Mineral. Petr., 150, 335-353, 2005.

Jabaloy-Sánchez, A., Azdimousa, A., Booth-Rea, G., Asebriy, L., Vázquez-Vílchez, M., Martínez-Martínez, J. M., and Gabites, J.: The structure of the Temsamane fold-andthrust stack (eastern Rif, Morocco): Evolution of a transpressional orogenic wedge, Tectonophysics, 663, 150-176, https://doi.org/10.1016/j.tecto.2015.02.003, 2015.

Jolivet, L. and Faccenna, C.: Mediterranean extension and the Africa-Eurasia collision, Tectonics, 19, 1095-1106, https://doi.org/10.1029/2000tc900018, 2000.

Jung, H., Park, M., Jung, S., and Lee, J.: Lattice preferred orientation, water content, and seismic anisotropy of orthopyroxene, J. Earth Sci., 21, 555-568, https://doi.org/10.1007/s12583-0100118-9, 2010.

Karato, S.-I.: Deformation of Earth materials: An introduction to the rheology of solid Earth, Cambridge University Press, Cambridge, New York, 463 pp., 2008.

Katayama, I., Jung, H., and Karato, S.-I.: New type of olivine fabric from deformation experiments at modest water content and low stress, Geology, 32, 1045, https://doi.org/10.1130/g20805.1, 2004.

Kelemen, P. B. and Dick, H. J. B.: Focused melt flow and localized deformation in the upper mantle - Juxtaposition of replacive dunite and ductile shear zones in the Josephine Peridotite, SW Oregon, J. Geophys. Res.-Sol. Ea., 100, 423-438, 1995.

Kourim, F., Vauchez, A., Bodinier, J.-L., Alard, O., and Bendaoud, A.: Subcontinental lithosphere reactivation beneath the Hoggar swell (Algeria): Localized deformation, melt channeling and heat advection, Tectonophysics, 650, 18-33, https://doi.org/10.1016/j.tecto.2014.11.012, 2015.

Kruckenberg, S. C., Tikoff, B., Toy, V. G., Newman, J., and Young, L. I.: Strain localization associated with channelized melt migration in upper mantle lithosphere: Insights from the Twin Sisters ultramafic complex, Washington, USA, J. Struct. Geol., 50, 133147, https://doi.org/10.1016/j.jsg.2012.10.009, 2013.

Lahmer, M. C., Seddiki, A., Zerka, M., Cottin, J.-Y., and Tabeliouna, M.: Metasomatism and origin of glass in the lithospheric mantle xenoliths beneath Ain Temouchent area (North-West Algeria), Arab. J. Geosci., 11, 332, https://doi.org/10.1007/s12517018-3684-2, 2018.

Lambart, S., Laporte, D., Provost, A., and Schiano, P.: Fate of Pyroxenite-derived Melts in the Peridotitic Mantle: Thermodynamic and Experimental Constraints, J. Petrol., 53, 451-476, https://doi.org/10.1093/petrology/egr068, 2012.
Le Roux, V., Tommasi, A., and Vauchez, A.: Feedback between melt percolation and deformation in an exhumed lithosphereasthenosphere boundary, Earth Planet. Sc. Lett., 274, 401-413, https://doi.org/10.1016/j.eps1.2008.07.053, 2008.

Linckens, J.: Microfabric evolution and strain localization in the naturally deformed mantle rocks, PhD, University of Bern, 160 pp., 2010.

Linckens, J., Herwegh, M., and Müntener, O.: Linking temperature estimates and microstructures in deformed polymineralic mantle rocks, Geochem. Geophy., Geosy. 12, Q08004, https://doi.org/10.1029/2011GC003536, 2011a.

Linckens, J., Herwegh, M., Müntener, O., and Mercolli, I.: Evolution of a polymineralic mantle shear zone and the role of second phases in the localization of deformation, J. Geophys. Res.Sol. Ea., 116, B06210, https://doi.org/10.1029/2010JB008119, $2011 b$.

Lonergan, L. and White, N.: Origin of the Betic-Rif mountain belt, Tectonics, 16, 504-522, https://doi.org/10.1029/96tc03937, 1997.

Louni-Hacini, A., Bellon, H., Maury, R. C., Megartsi, M., Coulon, C., Semroud, B., Cotten, J., and Coutelle, A.: $\mathrm{K}^{40}-\mathrm{Ar}^{40}$ dating of the late Miocene transition from calc-alkaline to alkali basalt series, northwestern Algeria, Comptes Rendus De L'Academie Des Sciences Serie Ii Fascicule a - Sciences De La Terre Et Des Planetes, 321, 975-982, 1995.

Mainprice, D., Tommasi, A., Couvy, H., Cordier, P., and Frost, D. J.: Pressure sensitivity of olivine slip systems and seismic anisotropy of Earth's upper mantle, Nature, 433, 731-733, 2005.

Mainprice, D., Bachmann, F., Hielscher, R., and Schaeben, H.: Descriptive tools for the analysis of texture projects with large datasets using MTEX: strength, symmetry and components, Geological Society, London, Special Publications, 409, https://doi.org/10.1144/sp409.8, 2014.

Mancilla, F. D. L., Booth-Rea, G., Stich, D., Pérez-Peña, J. V., Morales, J., Azañón, J. M., Martin, R., and Giaconia, F.: Slab rupture and delamination under the Betics and Rif constrained from receiver functions, Tectonophysics, 663, 225-237, https://doi.org/10.1016/j.tecto.2015.06.028, 2015.

Mancilla, F. D. L., Heit, B., Morales, J., Yuan, X., Stich, D., Molina-Aguilera, A., Azañon, J. M., and Martín, R.: A STEP fault in Central Betics, associated with lateral lithospheric tearing at the northern edge of the Gibraltar arc subduction system, Earth Planet. Sc. Lett., 486, 32-40, https://doi.org/10.1016/j.epsl.2018.01.008, 2018.

Marchesi, C., Konc, Z., Garrido, C. J., Bosch, D., Hidas, K., Varas-Reus, M. I., and Acosta-Vigil, A.: Multi-stage evolution of the lithospheric mantle beneath the westernmost Mediterranean: Geochemical constraints from peridotite xenoliths in the eastern Betic Cordillera (SE Spain), Lithos, 276, 75-89, https://doi.org/10.1016/j.lithos.2016.12.011, 2017.

Mauffret, A., Frizon de Lamotte, D., Lallemant, S., Gorini, C., and Maillard, A.: E-W opening of the Algerian Basin (Western Mediterranean), Terra Nova, 16, 257-264, https://doi.org/10.1111/j.1365-3121.2004.00559.x, 2004.

Maury, R. C., Fourcade, S., Coulon, C., El Azzouzi, M., Bellon, H., Coutelle, A., Ouabadi, A., Semroud, B., Megartsi, M., Cotten, J., Belanteur, Q., Louni-Hacini, A., Pique, A., Capdevila, R., Hernandez, J., and Rehault, J. P.: Post-collisional Neogene magmatism of the Mediterranean Maghreb margin: a consequence of 
slab breakoff, Comptes Rendus Acad. Sci. Ser II-A, 331, 159$173,2000$.

McDonough, W. F. and Sun, S.-S.: The composition of the Earth, Chem. Geol., 120, 223-253, 1995.

Medaouri, M., Déverchère, J., Graindorge, D., Bracene, R., Badji, R., Ouabadi, A., Yelles-Chaouche, K., and Bendiab, F.: The transition from Alboran to Algerian basins (Western Mediterranean Sea): Chronostratigraphy, deep crustal structure and tectonic evolution at the rear of a narrow slab rollback system, J. Geodynam., 77, 186-205, https://doi.org/10.1016/j.jog.2014.01.003, 2014.

Menant, A., Sternai, P., Jolivet, L., Guillou-Frottier, L., and Gerya, T.: 3D numerical modeling of mantle flow, crustal dynamics and magma genesis associated with slab roll-back and tearing: The eastern Mediterranean case, Earth Planet. Sc. Lett., 442, 93-107, https://doi.org/10.1016/j.epsl.2016.03.002, 2016.

Millen, D. W. and Hamburger, M. W.: Seismological evidence for tearing of the Pacific plate at the northern termination of the Tonga subduction zone, Geology, 26, 659-662, https://doi.org/10.1130/00917613(1998)026<0659:Seftot>2.3.Co;2, 1998.

Morales, L. F. G. and Tommasi, A.: Composition, textures, seismic and thermal anisotropies of xenoliths from a thin and hot lithospheric mantle (Summit Lake, southern Canadian Cordillera), Tectonophysics, 507, 1-15, https://doi.org/10.1016/j.tecto.2011.04.014, 2011.

Newman, J., Lamb, W. M., Drury, M. R., and Vissers, R. L. M.: Deformation processes in a peridotite shear zone: reactionsoftening by an $\mathrm{H}_{2} \mathrm{O}$-deficient, continuous net transfer reaction, Tectonophysics, 303, 193-222, https://doi.org/10.1016/S00401951(98)00259-5, 1999.

Nicolas, A., Boudier, F., and Boullier, A. M.: Mechanisms of flow in naturally and experimentally deformed peridotites, Am. J. Sci., 273, 853-876, 1973.

Nijholt, N. and Govers, R.: The role of passive margins on the evolution of Subduction-Transform Edge Propagators (STEPs), J. Geophys. Res.-Sol. Ea., 120, 7203-7230, https://doi.org/10.1002/2015JB012202, 2015.

Nimis, P. and Grütter, H.: Internally consistent geothermometers for garnet peridotites and pyroxenites, Contrib. Mineral. Petr., 159, 411-427, https://doi.org/10.1007/s00410-009-0455-9, 2010.

Parkinson, I. J., Arculus, R. J., and Eggins, S. M.: Peridotite xenoliths from Grenada, Lesser Antilles Island Arc, Contrib. Mineral. Petr., 146, 241-262, https://doi.org/10.1007/s00410-003-0500-z, 2003.

Pearce, J. A., Barker, P. F., Edwards, S. J., Parkinson, I. J., and Leat, P. T.: Geochemistry and tectonic significance of peridotites from the South Sandwich arc-basin system, South Atlantic, Contrib. Mineral. Petr., 139, 36-53, https://doi.org/10.1007/s004100050572, 2000.

Peslier, A. H., Francis, D., and Ludden, J.: The lithospheric mantle beneath continental margins: Melting and melt-rock reaction in Canadian Cordillera xenoliths, J. Petrol., 43, 2013-2047, 2002.

Phipps Morgan, J.: Melt migration beneath mid-ocean spreading centers, Geophys. Res. Lett., 14, 1238-1241, https://doi.org/10.1029/GL014i012p01238, 1987.

Pichavant, M. and Macdonald, R.: Crystallization of primitive basaltic magmas at crustal pressures and genesis of the calcalkaline igneous suite: experimental evidence from St Vin- cent, Lesser Antilles arc, Contrib. Mineral. Petr., 154, 535-558, https://doi.org/10.1007/s00410-007-0208-6, 2007.

Platt, J. P., Behr, W. M., Johanesen, K., and Williams, J. R.: The Betic-Rif Arc and Its Orogenic Hinterland: A Review, Ann. Rev. Earth Planet. Sci., 41, 313-357, https://doi.org/10.1146/annurevearth-050212-123951, 2013.

Precigout, J., Gueydan, F., Gapais, D., Garrido, C. J., and Essaifi, A.: Strain localisation in the subcontinental mantle - a ductile alternative to the brittle mantle, Tectonophysics, 445, 318-336, https://doi.org/10.1016/j.tecto.2007.09.002, 2007.

Raffone, N., Chazot, G., Pin, C., Vannucci, R., and Zanetti, A.: Metasomatism in the lithospheric mantle beneath middle Atlas (Morocco) and the origin of Fe- and Mg-rich wehrlites, J. Petrol., 50, 197-249, https://doi.org/10.1093/petrology/egn069, 2009.

Rampone, E., Piccardo, G. B., Vannucci, R., Bottazzi, P., and Ottolini, L.: Subsolidus reactions monitored by trace-element partitioning - the spinel-facies to plagioclase-facies transition in mantle peridotites, Contrib. Mineral. Petr., 115, 1-17, 1993.

Rampone, E., Vissers, R. L. M., Poggio, M., Scambelluri, M., and Zanetti, A.: Melt Migration and Intrusion during Exhumation of the Alboran Lithosphere: the Tallante Mantle Xenolith Record (Betic Cordillera, SE Spain), J. Petrol., 51, 295-325, https://doi.org/10.1093/petrology/egp061, 2010.

Rosenbaum, G., Lister, G. S., and Duboz, C.: Relative motions of Africa, Iberia and Europe during Alpine orogeny, Tectonophysics, 359, 117-129, https://doi.org/10.1016/s00401951(02)00442-0, 2002.

Roure, F., Casero, P., and Addoum, B.: Alpine inversion of the North African margin and delamination of its continental lithosphere, Tectonics, 31, TC3006, https://doi.org/10.1029/2011tc002989, 2012.

Royden, L. H.: Evolution of retreating subduction boundaries formed during continental collision, Tectonics, 12, 629-638, 1993.

Shaw, C. S. J.: Dissolution of orthopyroxene in basanitic magma between 0.4 and $2 \mathrm{GPa}$ : further implications for the origin of Si-rich alkaline glass inclusions in mantle xenoliths, Contrib. Mineral. Petr., 135, 114-132, 1999.

Shaw, C. S. J.: The temporal evolution of three magmatic systems in the West Eifel volcanic field, Germany, J. Volcanol. Geoth. Res., 131, 213-240, https://doi.org/10.1016/S0377-0273(03)00363-9, 2004.

Shaw, C. S. J., Eyzaguirre, J., Fryer, B., and Gagnon, J.: Regional Variations in the Mineralogy of Metasomatic Assemblages in Mantle Xenoliths from the West Eifel Volcanic Field, Germany, J. Petrol., 46, 945-972, https://doi.org/10.1093/petrology/egi006, 2005.

Skemer, P., Katayama, I., Jiang, Z., and Karato, S.-I.: The misorientation index: Development of a new method for calculating the strength of lattice-preferred orientation, Tectonophysics, 411, 157-167, https://doi.org/10.1016/j.tecto.2005.08.023, 2005.

Skemer, P., Warren, J. M., Kelemen, P. B., and Hirth, G.: Microstructural and Rheological Evolution of a Mantle Shear Zone, J. Petrol., 51, 43-53, https://doi.org/10.1093/petrology/egp057, 2010.

Soustelle, V., Tommasi, A., Bodinier, J. L., Garrido, C. J., and Vauchez, A.: Deformation and reactive melt transport in the mantle lithosphere above a large-scale partial melting domain: the 
Ronda Peridotite Massif, southern Spain, J. Petrol., 50, 12351266, https://doi.org/10.1093/petrology/egp032, 2009.

Soustelle, V., Tommasi, A., Demouchy, S., and Ionov, D. A.: Deformation and Fluid-Rock Interaction in the Supra-subduction Mantle: Microstructures and Water Contents in Peridotite Xenoliths from the Avacha Volcano, Kamchatka, J. Petrol., 51, 363394, https://doi.org/10.1093/petrology/egp085, 2010.

Spakman, W. and Wortel, R.: A tomographic view on western Mediterranean geodynamics, in: The TRANSMED atlas - The Mediterranean region from crust to mantle, edited by: Cavazza, W., Roure, F., Spakman, W., Stampfli, G. M., and Ziegler, P. A., Springer, Berlin Heidelberg, 31-52, 2004.

Streckeisen, A.: To each plutonic rock its proper name, Earth-Sci. Rev., 12, 1-33, 1976.

Suhr, G.: Evaluation of upper mantle microstructures in the Table Mountain massif (Bay of Islands ophiolite), J. Struct. Geol., 15, 1273-1292, https://doi.org/10.1016/0191-8141(93)90102-G, 1993.

Tasaka, M. and Hiraga, T.: Influence of mineral fraction on the rheological properties of forsterite plus enstatite during grain-size-sensitive creep: 1 . Grain size and grain growth laws, J. Geophys. Res.-Sol. Ea., 118, 3970-3990, https://doi.org/10.1002/jgrb.50285, 2013.

Tasaka, M., Hiraga, T., and Michibayashi, K.: Influence of mineral fraction on the rheological properties of forsterite + enstatite during grain size sensitive creep: 3, Application of grain growth and flow laws on peridotite ultramylonite, J. Geophys. Res.-Sol. Ea., 119, 840-857, https://doi.org/10.1002/2013JB010619, 2014.

Tommasi, A. and Vauchez, A.: Heterogeneity and anisotropy in the lithospheric mantle, Tectonophysics, 661, 11-37, https://doi.org/10.1016/j.tecto.2015.07.026, 2015.

Tommasi, A., Tikoff, B., and Vauchez, A.: Upper mantle tectonics: three-dimensional deformation, olivine crystallographic fabrics and seismic properties, Earth Planet. Sc. Lett., 168, 173-186, 1999.

Tommasi, A., Mainprice, D., Canova, G., and Chastel, Y.: Viscoplastic self-consistent and equilibrium-based modeling of olivine lattice preferred orientations: Implications for the upper mantle seismic anisotropy, J. Geophys. Res.-Sol. Ea., 105, 78937908, 2000.

Tommasi, A., Godard, M., Coromina, G., Dautria, J. M., and Barsczus, H.: Seismic anisotropy and compositionally induced velocity anomalies in the lithosphere above mantle plumes: a petrological and microstructural study of mantle xenoliths from French Polynesia, Earth Planet. Sc. Lett., 227, 539-556, https://doi.org/10.1016/j.epsl.2004.09.019, 2004.

Tommasi, A., Vauchez, A., and Ionov, D. A.: Deformation, static recrystallization, and reactive melt transport in shallow subcontinental mantle xenoliths (Tok Cenozoic volcanic field, SE Siberia), Earth Planet. Sc. Lett., 272, 65-77, https://doi.org/10.1016/j.epsl.2008.04.020, 2008.

Turner, S. P., Platt, J. P., George, R. M. M., Kelley, S. P., Pearson, D. G., and Nowell, G. M.: Magmatism associated with orogenic collapse of the Betic-Alboran domain, SE Spain, J. Petrol., 40, 1011-1036, https://doi.org/10.1093/petroj/40.6.1011, 1999.

Urai, J. L., Means, W. D., and Lister, G. S.: Dynamic recrystallization of minerals, in: Mineral and rock deformation: laboratory studies (the Paterson volume), edited by: Hobbs, B. E. and
Heard, H. C., Geophysical Monograph 36, American Geophysical Union, Washington, D.C., 161-199, 1986.

van Hinsbergen, D. J. J., Vissers, R. L. M., and Spakman, W.: Origin and consequences of western Mediterranean subduction, rollback, and slab segmentation, Tectonics, 33, 2013TC003349, https://doi.org/10.1002/2013TC003349, 2014.

Varas-Reus, M. I., Garrido, C. J., Marchesi, C., Bodinier, J.L., Frets, E., Bosch, D., Tommasi, A., Hidas, K., and Targuisti, K.: Refertilization Processes in the Subcontinental Lithospheric Mantle: the Record of the Beni Bousera Orogenic Peridotite (Rif Belt, Northern Morocco), J. Petrol., 57, 2251-2270, https://doi.org/10.1093/petrology/egx003, 2016.

Varas-Reus, M. I., Garrido, C. J., Marchesi, C., Bosch, D., AcostaVigil, A., Hidas, K., Barich, A., and Booth-Rea, G.: Sr-Nd-Pb isotopic systematics of crustal rocks from the western Betics (S. Spain): Implications for crustal recycling in the lithospheric mantle beneath the westernmost Mediterranean, Lithos, 276, 45-61, https://doi.org/10.1016/j.lithos.2016.10.003, 2017.

Vauchez, A., Dineur, F., and Rudnick, R.: Microstructure, texture and seismic anisotropy of the lithospheric mantle above a mantle plume: Insights from the Labait volcano xenoliths (Tanzania), Earth Planet. Sc. Lett., 232, 295-314, 2005.

Vauchez, A., Tommasi, A., and Mainprice, D.: Faults (shear zones) in the Earth's mantle, Tectonophysics, 558, 1-27, https://doi.org/10.1016/j.tecto.2012.06.006, 2012.

Vollmer, F. W.: An application of eigenvalue methods to structural domain analysis, Geol. Soc. Am. Bull., 102, 786-791, https://doi.org/10.1130/00167606(1990)102<0786:aaoemt>2.3.co;2, 1990.

Warren, J. M. and Hirth, G.: Grain size sensitive deformation mechanisms in naturally deformed peridotites, Earth Planet. Sc. Lett., 248, 438-450, https://doi.org/10.1016/j.epsl.2006.06.006, 2006.

Wilson, J. T.: A New Class of Faults and their Bearing on Continental Drift, Nature, 207, 343-347, https://doi.org/10.1038/207343a0, 1965.

Witt-Eickschen, G. and Seck, H. A.: Solubility of Ca and Al in orthopyroxene from spinel peridotite - an improved version of an empirical geothermometer, Contrib. Mineral. Petr., 106, 431439, 1991.

Workman, R. K. and Hart, S. R.: Major and trace element composition of the depleted MORB mantle (DMM), Earth Planet. Sc. Lett., 231, 53-72, https://doi.org/10.1016/j.eps1.2004.12.005, 2005.

Wright, S. I., Nowell, M. M., and Field, D. P.: A review of strain analysis using electron backscatter diffraction, Microscopy and microanalysis: the official journal of Microscopy Society of America, Microbeam Analysis Society, Microscopical Society of Canada, 17, 316-329, https://doi.org/10.1017/s1431927611000055, 2011.

Yang, K., Hidas, K., Falus, G., Szabo, C., Nam, B., Kovacs, I., and Hwang, B.: Relation between mantle shear zone deformation and metasomatism in spinel peridotite xenoliths of Jeju Island (South Korea): Evidence from olivine CPO and trace elements, J. Geodynam., 50, 424-440, https://doi.org/10.1016/j.jog.2010.05.005, 2010.

Yaxley, G. M., Cranwford, A. J., and Green, D. H.: Evidence for carbonatite metasomatism in spinel peridotite xenoliths from western Victoria, Australia, Earth Planet. Sc. Lett., 107, 305-317, 1991. 
Zaffarana, C., Tommasi, A., Vauchez, A., and Grégoire, M.: Microstructures and seismic properties of south Patagonian mantle xenoliths (Gobernador Gregores and Pali Aike), Tectonophysics, 621, 175-197, https://doi.org/10.1016/j.tecto.2014.02.017, 2014.
Zerka, M., Cottin, J. Y., Gregoire, M., Lorand, J. P., Megartsi, M., and Midoun, M.: Ultramafic xenoliths from Quaternary alkali volcanism from Oranie (Tell, western Algeria): witnesses of a sheared and enriched lithosphere, C. R. Geosci., 334, 387-394, https://doi.org/10.1016/s1631-0713(02)01771-6, 2002.

Zimmerman, M. E. and Kohlstedt, D. L.: Rheological Properties of Partially Molten Lherzolite, J. Petrol., 45, 275-298, https://doi.org/10.1093/petrology/egg089, 2004. 